\title{
AVALIAÇÃO DA QUALIDADE DA ÁGUA DE NASCENTES (BICAS) EM PIRACICABA (SP), QUANTO À PRESENÇA DE INDICADORES DE CONTAMINAÇÃO FECAL
}

\author{
DENISE ALVES GONÇALVES BATISTA
}

Dissertação apresentada à Escola Superior de Agricultura "Luiz de Queiroz", da Universidade de São Paulo, para obtenção do título de Mestre em Ciências, Área de Concentração: Ciência e Tecnologia de Alimentos.

PIRACICABA

Estado de São Paulo - Brasil

Março de 1996 
Dados Internacionais de Catalogação na Publicação (CIP) DIVISÃO DE BIBLIOTECA E DOCUMENTAÇẨO - Campus “Luiz de Queiroz"/USP

Batista, Denise Alves Gonçalves

Avaliaçāo da qualidade da água de nascentes (Bicas) em Piracicaba (SP), quanto à presença de indicadores de contaminação fecal / Denise Alves Gonçalves Batista. - - Piracicaba, 1996.

86p.

Dissertaçāo (mestrado) - - Escola Superior de Agricultura Luiz de Queiroz, 1996.

Bibliografia.

1. Água - Qualidade - Piracicaba 2. Nascente de água - Contaminação - Pi racicaba I. Título

CDD 628.16 


\title{
AVALIAÇÃO DA QUALIDADE DA ÁGUA DE NASCENTES (BICAS)EM PIRACICABA (SP), QUANTO À PRESENÇA DE INDICADORES DE CONTAMINAÇÃO FECAL
}

\author{
DENISE ALVES GONÇALVES BATISTA
}

Aprovada em: 29.04 .96

Comissão Julgadora:

Prof. Dr. Claudio Rosa Gallo

ESALQ/USP

Prof $^{\mathrm{e}} \mathrm{Dr}^{\mathrm{a}}$ Marília Oetterer ESALQ/USP

Prof $^{\mathbb{a}} \mathrm{Dr}^{\mathrm{a}}$ Dejanira de Franceschi de Angelis

IBCR/UNESP

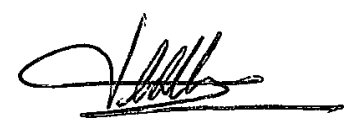

Orientador: Prof. Dr. CLAUDIO ROSA GALLO 
À meus pais Júlio e Elenice e ao meu marido Leonel, por mais esta conquista.

\section{DEDICO}

Ao Álvaro, Nicole e Marsel

OFEREÇO 


\section{AGRADECIMENTOS}

- À Deus, sem o qual nada seria possível;

- À Escola Superior de Agricultura "Luiz de Queiroz"/USP e ao Departamento de Ciência e Tecnologia Agroindustrial;

- Ao Prof. Dr. Claudio Rosa Gallo pela competência na orientação, amizade, dedicação e apoio na elaboração deste trabalho;

- À CAPES, pela bolsa concedida;

- À FAPESP, pelo auxílio-pesquisa concedido;

- A todos que, direta ou indiretamente, colaboraram para tomar possível este trabalho de pesquisa.

- Aos colegas do curso de Pós-Graduação em Ciência e Tecnologia de Alimentos que tornaram mais agradável esta etapa percorrida. 


\section{ÍNDICE}

\section{Pág.}

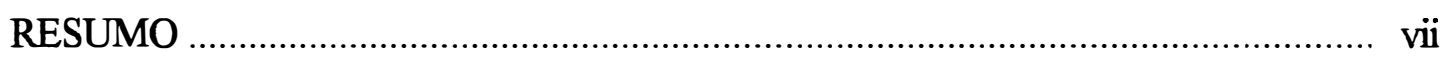

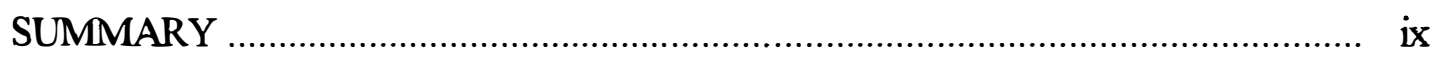

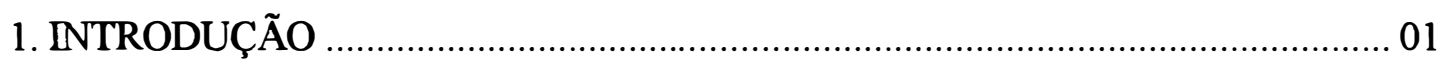

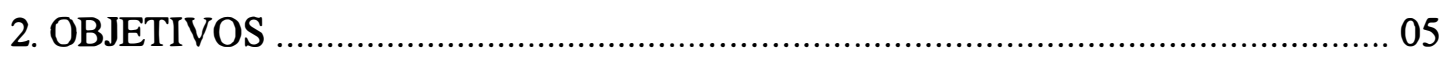

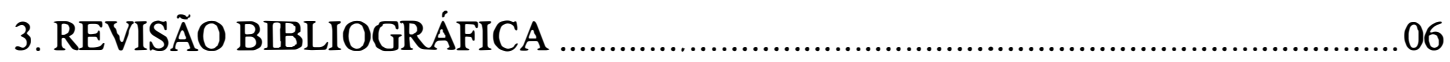

3.1. Principais doenças de transmissão hídrica e suas consequências na ausência de tratamento 09

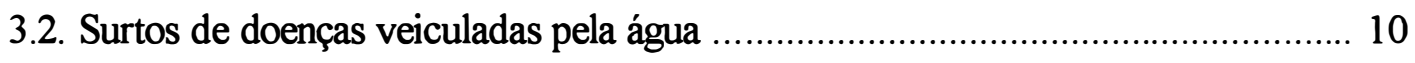

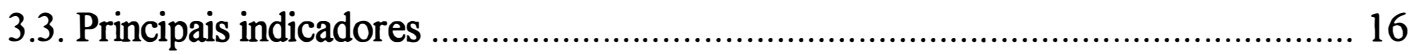

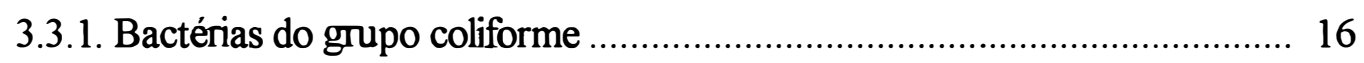

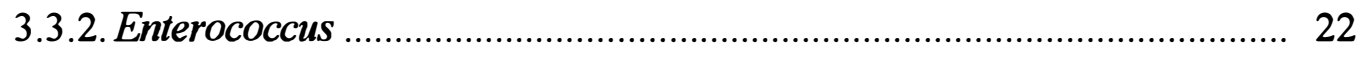

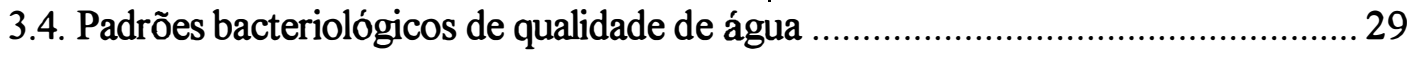

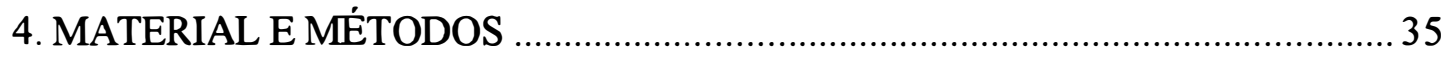

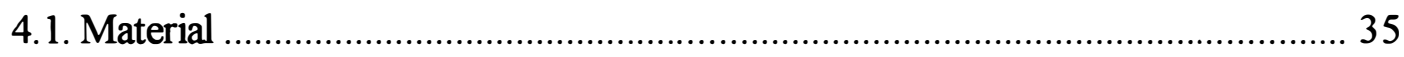

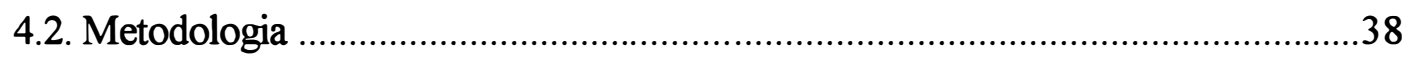



4.2.2. Determinação de coliformes totais e fecais pela técnica de tubos múlti-

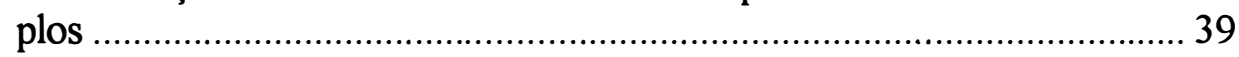

4.2.3. Determinação de Enterococcus pela técnica de tubos múltiplos ................ 45

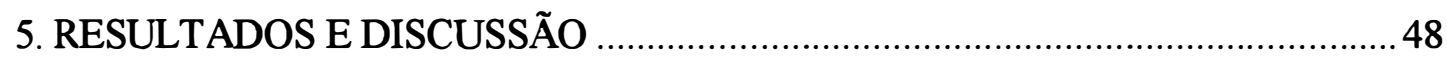

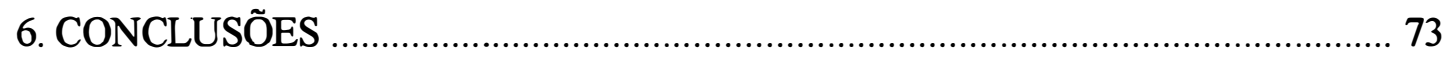

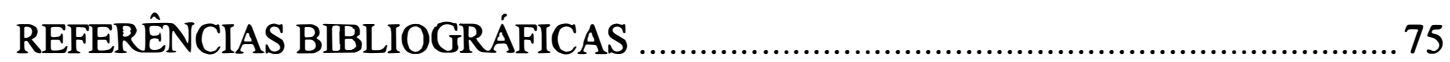




\section{ÍNDICE DE FIGURAS}

Figura 1. Mapa com a localização das 8 nascentes (bicas) na cidade de Piracicaba - SP 39

Figura 2. Esquema do procedimento para determinação de Coliformes Fecais (Técnica de Tubos Múltiplos). Fonte: CETESB, 1991

Figura 3. Esquema do procedimento para determinação de Enterococcus (Técnica de Tubos Múltiplos). Fonte: CETESB, 1991

Figura 4. Número Mais Provável (NMP) de Coliformes Totais, Coliformes Fecais e Enterococcus $/ 100 \mathrm{ml}$ de água nas 18 coletas da nascente 1

Figura 5. Número Mais Provável (NMP) de Coliformes Totais, Coliformes Fecais e Enterococcus $/ 100 \mathrm{ml}$ de água nas 18 coletas da nascente 2

Figura 6. Número Mais Provável (NMP) de Coliformes Totais, Coliformes Fecais e Enterococcus $/ 100 \mathrm{ml}$ de água nas 18 coletas da nascente 3

Figura 7. Número Mais Provável (NMP) de Coliformes Totais, Coliformes Fecais e Enterococcus/100 $\mathrm{ml}$ de água nas 18 coletas da nascente 4

Figura 8. Número Mais Provável (NMP) de Coliformes Totais, Coliformes Fecais e Enterococcus $/ 100 \mathrm{ml}$ de água nas 18 coletas da nascente 5

Figura 9. Número Mais Provável (NMP) de Coliformes Totais, Coliformes Fecais e Enterococcus $/ 100 \mathrm{ml}$ de água nas 18 coletas da nascente 6

Figura 10. Número Mais Provável (NMP) de Coliformes Totais, Coliformes Fecais e Enterococcus/ $100 \mathrm{ml}$ de água nas 18 coletas da nascente 7

Figura 11. Número Mais Provável (NMP) de Coliformes Totais, Coliformes Fecais e Enterococcus/100 $\mathrm{ml}$ de água nas 18 coletas da nascente 8

Figura 12. Percentuais de contaminação por coliformes totais, coliformes fecais e Enterococcus, nas amostras da nascente 1

Figura 13. Percentuais de contaminação por coliformes totais, coliformes fecais e Enterococcus, nas amostras da nascente 2 
Figura 14. Percentuais de contaminação por coliformes totais, coliformes fecais e Enterococcus, nas amostras da nascente 3

Figura 15. Percentuais de contaminação por coliformes totais, coliformes fecais e Enterococcus, nas amostras da nascente 4

Figura 16. Percentuais de contaminação por coliformes totais, coliformes fecais e Enterococcus, nas amostras da nascente 5

Figura 17. Percentuais de contaminação por coliformes totais, coliformes fecais e Enterococcus, nas amostras da nascente 6

Figura 18. Percentuais de contaminação por coliformes totais, coliformes fecais e Enterococcus, nas amostras da nascente 7

Figura 19. Percentuais de contaminação por coliformes totais, coliformes fecais e Enterococcus, nas amostras da nascente 8 


\section{ÍNDICE DE TABELAS}

Pág.

Tabela 1. Doenças causadas pelos principais microrganismos que podem estar presentes em esgotos domésticos

Tabela 2. Número Mais Provável (NMP) de Coliformes e Enterococcus/100ml de água Nascente 1

Tabela 3. Número Mais Provável (NMP) de Coliformes e Enterococcus/100ml de água Nascente 2

Tabela 4. Número Mais Provável (NMP) de Coliformes e Enterococcus/100ml de água Nascente 3

Tabela 5. Número Mais Provável (NMP) de Coliformes e Enterococcus/100ml de água Nascente 4

Tabela 6. Número Mais Provável (NMP) de Coliformes e Enterococcus/100ml de água Nascente 5

Tabela 7. Número Mais Provável (NMP) de Coliformes e Enterococcus/100ml de água Nascente 6

Tabela 8. Número Mais Provável (NMP) de Coliformes e Enterococcus/100ml de água Nascente 7

Tabela 9. Número Mais Provável (NMP) de Coliformes e Enterococcus/100ml de água Nascente 8

Tabela 10. Condições climáticas nos dias de coleta 


\title{
AVALIAÇÃO DA QUALIDADE DA ÁGUA DE NASCENTES (BICAS) EM PIRACICABA (SP), QUANTO À PRESENÇA DE INDICADORES DE CONTAMINAÇÃO FECAL
}

\author{
Autora: Denise Alves Gonçalves Batista \\ Orientador: Prof. Dr. Claudio Rosa Gallo
}

\section{RESUMO}

Devido a tradição do consumo de água de bica em Piracicaba - SP e visto que a contaminação por excretas humanas ou animais pode tomá-las um veículo de doenças infecciosas e parasitárias, o presente estudo teve como objetivo avaliar a qualidade da água em função da ocorrência de indicadores de contaminação fecal (coliformes e Enterococcus).

Foram analisadas 18 amostras quinzenais de 8 nascentes (bicas) da cidade de Piracicaba - SP, totalizando assim 144 amostras, escolhidas por serem as de maior procura pela população, utilizando-se a metodologia da Companhia de Tecnologia de Saneamento Ambiental - CETESB (1991).

Os padrões utilizados para a avaliação da qualidade da água foram aqueles estabelecidos pela legislação brasileira federal, estadual e pela internacional (OMS).

Com os resultados vê-se que a água de 7 (87,5\%) das 8 nascentes (bicas) analisadas estão impróprias para o consumo humano, algumas com índices de contaminação maiores, como por exemplo as nascentes de números $1,2,5$ e 7 onde $100 \%$ das amostras analisadas apresentaram-se contaminadas por coliformes totais. 
A nascente (bica) 3 foi a única que não apresentou contaminação por coliformes fecais e por Enterococcus, apresentando contaminação por coliformes totais em apenas 2 das 18 coletas e com menos de 10 coliformes totais $/ 100 \mathrm{ml}$ de água em coletas não consecutivas, o que enquadra a água desta nascente como potável, ou própria ao consumo humano.

A presença de Enterococcus nas mesmas 7 (87,5\%) das 8 nascentes (bicas) que haviam apresentado contaminação por coliformes, vem confirmar a não potabilidade bacteriológica da água das mesmas.

Em algumas amostras não se detectou coliformes fecais e se detectou Enterococcus ou vice-versa, mostrando que a análise simultânea para os dois gnupos de indicadores fecais é importante para uma melhor avaliação da qualidade bacteriológica da água.

Embora não tenha ficado bem caracterizada a influência direta das chuvas, em algumas nascentes, as maiores contaminações foram detectadas, ou em dias chuvosos de coletas ou após período chuvoso. 


\title{
EVALUATION OF THE NATURAL FOUNTAINS WATER QUALTY IN PIRACICABA CITY, SÃO PAULO STATE REGARDING THE PRESENCE OF FECAL CONTAMINATION INDICATORS
}

\author{
Author: Denise Alves Gonçalves Batista \\ Adviser: Prof. Dr. Claudio Rosa Gallo
}

\section{SUMMARY}

It is common pratice in Piracicaba city, São Paulo State, Brazil to consume water from natural fountains where there is iminent risk of contaminatoin with human and animal feces, making the water a vehicle of infections and parasite diseases. The objetive of this study was to evaluate the water quality of these natural fountains regarding the occurrence of fecal contamination indicators (coliforms and Enterococcus).

18 samples were taken every 15 days from 8 fountains located in town, chosen by population preference. A total of 144 samples were analysed according to CETESB (1991)'s recommended methodology.

Standards were those established by brasilian federal, state and international (OMS) legislations.

Results indicated that 7 from 8 fountains analysed were not recommended for human consumption, four of them showing contamination levels extremely high, where $100 \%$ of the samples were contaminated by fecal coliforms. $87.5 \%$ of these samples also presented contamination by Enterococcus, confirming their non-potability. Either analysis had 
positive results, confiming that waters should be submitted to both analysis for a better bacteriological quality evaluation.

Only one of them did not show contamination by fecal coliforms and by Enterococcus, although total coliforms were detected in 2 of 18 samples, with less than 10 total coliforms $/ 100 \mathrm{ml}$ water in non-consecutive sampling, which indicates potability.

Although the influence of the incidence of rains has not been characterized, highest contamination was detected either in rainy days or right after a rainy period. 


\section{INTRODUÇÃO}

A água constitui um dos elementos fundamentais para a existência do homem. Suas funções no abastecimento público, industrial e agropecuário, na preservação da vida aquática, na recreação e no transporte demonstram essa importância vital. Tanto é a sua importância que a FAO escolheu como tema do ano de 1994 "Água para vida".

É conveniente lembrar que, embora a água cubra aproximadamente três quartos da superfície da terra, $97,4 \%$ é salgada e se encontra nos oceanos e $1,8 \%$ está congelada e se localiza nas regiões polares; portanto, a água doce, disponível para a população do nosso planeta representa apenas $0,8 \%$, e desta, não se conhece qual é a fração que se encontra contaminada (CETESB, 1991; ÁGUA, 1994).

As águas naturais não só contém a flora microbiana habitual, como também microrganismos do solo e possivelmente dos animais e inclusive material fecal.

Segundo MARMO \& JOLY (1964a e b), exames bacteriológicos realizados com amostras de águas das mais diversas origens, em Piracicaba, tanto superficiais, como de profundidade, revelaram que, com muita frequência, a maioria das águas naturais se apresenta contaminada, sendo que o grau atingido tem-se mostrado tanto maior quanto mais 
próximas essas águas se encontram dos centros demográficos. A contaminação pode mesmo ser considerada como um tributo que se paga à civilização atual.

Essa contaminação que vem ocorrendo ao longo dos anos é causada pelo desenvolvimento industrial, pelo crescimento demográfico e pela ocupação de solo de forma intensa e acelerada, provocando o comprometimento dos recursos hídricos disponíveis para o consumo humano, recreação e múltiplas atividades, aumentando consideravelmente o risco de doenças de transmissão de origem hídrica (BATALHA, s.d.; CETESB, 1991).

Mesmo algum tempo antes de ser aceito o binômio bactéria-doença, na Inglaterra, conseguiu-se demonstrar, pela primeira vez, por meio de estatística e não com técnicas de laboratório, que um surto epidêmico de cólera-morbo que ocorreu em Board Street e vizinhanças, em Londres, tinha origem em germes transmitidos por meio de água de beber, devido a um desarranjo do sistema de esgotos. Foi só bem depois disso que os germes específicos, de várias doenças de veiculação hídrica, foram descobertos (febre tifóide,1880, por Eberth; cólera-morbo, 1884,por Koch; disenteria, 1898, por Shiga; e febre paratifóide, 1902, por Kayser) (MARMO \& JOLY, 1964a e b; ELLIS, 1991).

Somente após essas descobertas é que se passou a aceitar como verdade que as águas tornavam-se veículos dos germes patogênicos responsáveis por distúrbios intestinais, oriundos de excrementos provindos de doentes com disenterias (Shigella), febre tifóide (Salmonella) e cólera (Vibrio).

Segundo dados da Organização Mundial de Saúde (OMS), $80 \%$ das doenças que ocorrem nos países em desenvolvimento são ocasionadas pela contaminação da água. 
Sabe-se também que, a cada ano, 15 milhões de crianças até 5 anos morrem direta ou indiretamente pela falta ou deficiência dos sistemas de abastecimento de águas e esgotos. De acordo com a Associação Brasileira de Engenharia Sanitária (ABES), o ressurgimento de doenças consideradas erradicadas no Brasil é consequência direta da fragilidade do sistema de saneamento. A entidade funda-se, para fazer essa assertiva, em estudos da Organização Mundial de Saúde (OMS), segundo os quais a carência de água e esgoto é responsável por $80 \%$ das moléstias que afetam a população e por $65 \%$ das internações hospitalares (A CAUSA....., 1993).

Somente $30 \%$ da população mundial tem garantia de água tratada, sendo que os $70 \%$ restantes dependem de poços e outras fontes de abastecimento passíveis de contaminação.

A preservação da qualidade das águas é uma necessidade universal, que exige atenção por parte dos governos, através de orgãos de saneamento, particularmente em relação aos mananciais e águas de consumo humano, visto que sua contaminação por excretas de origem humana ou animal pode torná-las um veículo na transmissão de agentes de doenças infecciosas e parasitárias. Por isso impõe-se a necessidade de exames rotineiros das mesmas, para a avaliação de sua qualidade do ponto de vista bacteriológico (CETESB, 1991).

A cidade de Piracicaba tem uma longa tradição de consumo de água de bica. Como as bicas proliferam às dezenas, parte da população está acostumada a recorrer a elas, mantendo um costume que atinge seu pico na época da estiagem, quando a poluição. 

aumenta consideravelmente nos rios Piracicaba e Corumbataí (que abastecem a cidade) e obriga o SEMAE a um tratamento mais rigoroso na água distribuída à população (PIRACICABA, 1993). 


\section{OBJETIVOS}

O presente estudo têve como objetivo avaliar a qualidade da água em função da ocorrência de indicadores de contaminação fecal (coliformes e Enterococcus) das nascentes (bicas) da cidade de Piracicaba, visto que a contaminação por excretas humanas ou animais pode torná-las um veículo na transmissão de agentes de doenças infecciosas e parasitárias. Outra finalidade é contribuir com informações que poderão alertar e auxiliar os orgãos governamentais de saúde pública para um melhor controle e se necessário até a interdição das nascentes (bicas) a fim de evitar riscos de doenças de veiculação hídrica. 


\section{REVISÃO BIBLIOGRÁFICA}

Os microrganismos são encontrados em quase todos os ambientes aquáticos, desde pequenos riachos aos grandes oceanos, oferecendo uma variedade grande de habitação e nichos ecológicos (HAGLER \& MENDONÇA-HAGLER, 1991).

As águas subterrâneas atingem a superfície dando origem às nascentes, colonizadas predominantemente pelas bactérias e algas.

Segundo os mesmos autores, os gêneros bacterianos prevalentes nas nascentes são Alcaligenes, Flavobacterium, Acinetobacter, Moraxella, Pseudomonas, Micrococcus, Nocardia e Cytophaga, além de bactérias ramificadas como Hypomycrobium, Caulobacter e Gallionella.

Nas águas de nascentes com teor elevado de matéria orgânica aumenta a propagação de espécies incluídas nas familias Pseudomonadaceae, Enterobacteriaceae e Bacillaceae.

Água poluida é a maior causa de doenças, misérias e morte. De acordo com a OMS, mais de 4 milhões de crianças morrem todo ano como resultado de diarréia causada por doenças transmitidas pela água. Nenhuma dessas mortes teria acontecido se as normas de saneamento há muito tidas como essenciais nos países desenvolvidos tivessem 
sido exigidas nos países em desenvolvimento. Mesmo no final da "Década Internacional da Água Potável e Saneamento" (1981-1990), 31\% da população não teve acesso a água potável e $46 \%$ não tem saneamento adequado (FAO, 1994).

Uma série de doenças pode estar associada à água, seja em decorrência de sua contaminação por excretas humanos ou de outros animais, seja pela presença de substâncias químicas nocivas à saúde humana.

Tradicionalmente, as doenças relacionadas com a água vêm sendo classificadas em dois grupos:

- Doenças de transmissão hídrica: são aquelas em que a água atua como veículo do agente infeccioso. Os microrganismos patogênicos atingem a água através de excretas de pessoas ou animais infectados, causando problemas principalmente no aparelho gastrointestinal do homem. Essas doenças podem ser causadas por bactérias, vírus, protozoários e helmintos.

Doenças de origem hídrica: são aquelas causadas por determinadas substâncias químicas, orgânicas ou inorgânicas, presentes na água em concentrações inadequadas, em geral superiores às especificadas nos padrões para água de consumo humano. Essas substâncias podem existir naturalmente no manancial ou resultarem da poluição. São exemplos de doenças de origem hídrica: o saturnismo - provocado por excesso de chumbo na água e a matemoglobinemia em crianças - 
decorrente da ingestão de concentrações excessivas de nitrato (VERTONI \& GALLO, 1994).

Entre os principais agentes etiológicos implicados em doenças de transmissão hídrica, incluem-se os relacionados na Tabela seguinte:

Tabela 1. Doenças causadas pelos principa is microrganismos que podem estar presentes em esgotos domésticos.

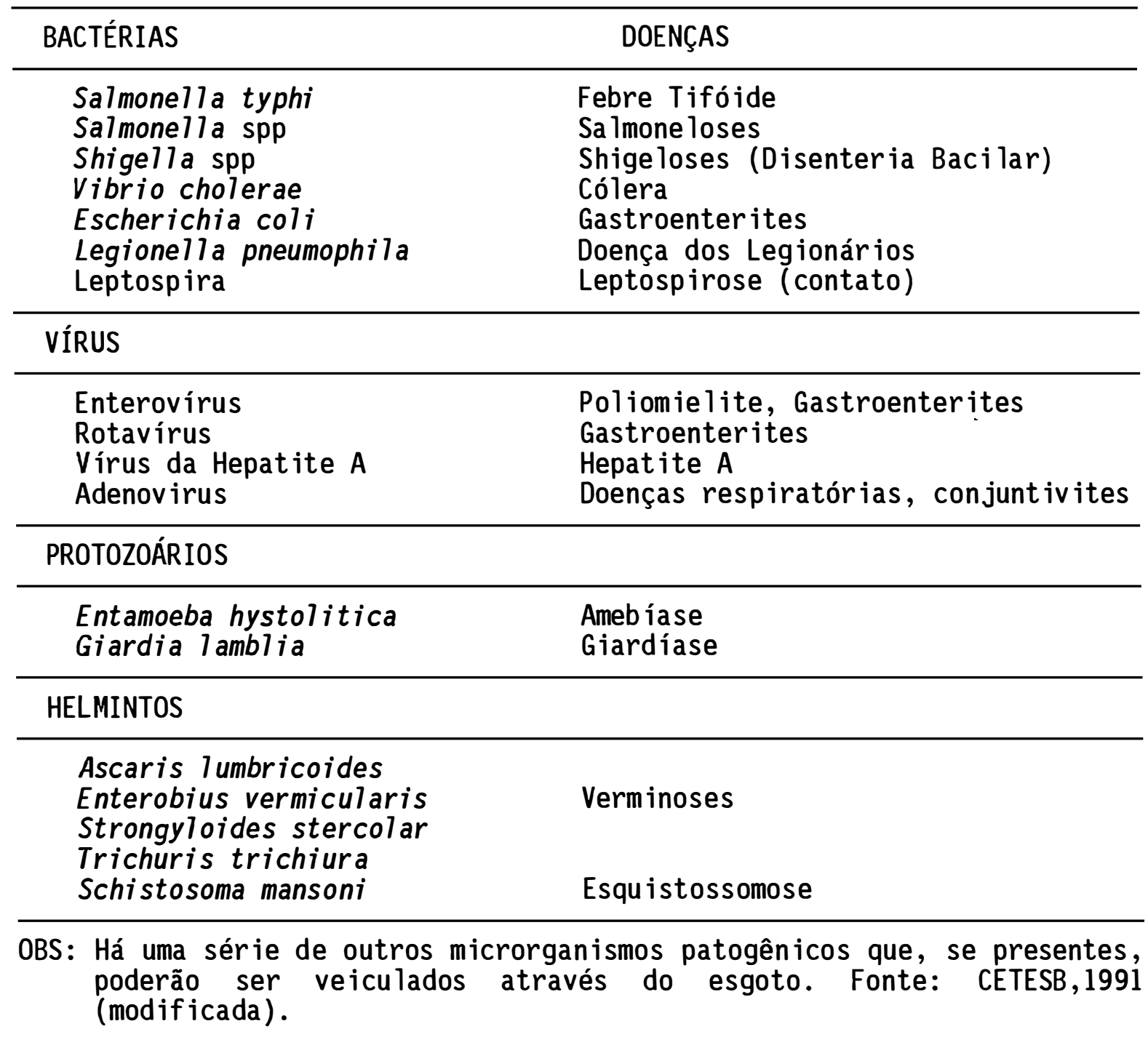


3.1. Principais doenças de transmissão hídrica e suas consequências na saúde da população

Febre tifóide - a taxa de mortalidade é de $10 \%$ na ausência de tratamento.

Febre Paratifóide - sua letalidade é mais baixa que a anterior.

Outras salmoneloses - taxa de mortalidade é baixa, exceto entre crianças, idosos e pessoas debilitadas, devido à desidratação.

Shigeloses - infecção grave com taxa significativa de mortalidade, especialmente em recém-nascidos, crianças e indivíduos debilitados.

Cólera - taxa de letalidade em pacientes não tratados pode ultrapassar $50 \%$ embora, com tratamento adequado, atualmente seja menor que $1 \%$.

Poliomielite - em menos de 10 anos a vacina contra a poliomielite fez desaparecer a doença paralítica: na Suécia, pela vacinação com vírus mortos e no oeste da Europa e na América do Norte, pela vacinação com vírus vivos. Nos Estados Unidos a mortalidade passou de 20.000 casos por ano, em 1950, para 28 casos em 1967 (MANDE, 1968).

A imunização contra a poliomielite é um dos maiores sucessos da medicina preventiva (BEALE, 1969). As grandes campanhas da vacinação contra a poliomielite, iniciadas, nos países desenvolvidos, há cerca de duas décadas com a utilização de vírus inativos, seguidas de imunização rotineira dos novos suscetíveis, permitiram o efetivo 
controle dessa virose, traduzido pela sua virtual eliminação nessas regiões (BARBOSA et al., 1984).

O "Programa Nacional de Vacinação contra a Poliomielite", iniciado em junho de 1980, alcançou, sem dúvida, alentadores resultados na Região da Grande São Paulo, ao permitir sensível diminuição da incidência de casos dessa virose entre nós, comprovada pela ocorrência de somente 4 casos em 1981, contrastando com a média anual de aproximadamente 122 casos no período de 1975 a 1980 (WALDMAN et al., 1983). Pelos dados veiculados pela imprensa, a vacinação em massa alcançou plenamente seus objetivos pois nos últimos anos nenhum caso da doença foi relatado no país.

\subsection{Surtos de Doenças Veiculadas pela Água}

De 1986 até 1988, 24 estados dos Estados Unidos e Porto Rico relataram 50 surtos de doenças relacionadas com água para consumo afetando 25.846 pessoas, onde Giardia lamblia foi identificada como agente etiológico em 9 (18\%) dos surtos afetando 274 pessoas em 1986, 633 pessoas em 1987 e 262 pessoas em 1988; Shigella sonnei afetou 33 pessoas em 1986, 1800 péssoas em 1987 e 900 pessoas em 1988; Salmonella afetou 70 pessoas em 1986; Campylobacter afetou 250 pessoas em 1986; Norwalk afetou 1 pessoa em 1986, 5000 pessoas em 1987 e 339 em 1988 (LEVINE et al., 1991).

Em 1984 sete incidentes foram documentados no Canadá, onde poços contaminados foram responsáveis por três surtos na cidade e dois no campo. $\mathrm{O}$ número de 
pessoas afetadas variou de 1 até 70 e em somente 2 desses casos foram identificados os patógenos responsáveis (Campylobacter e Yersinia). Ainda um surto de salmonelose envolvendo 76 pessoas foi relacionado com a água do município de Quebec, Canadá (TODD, 1989).

Em 1991 e 1992, foram relatados 34 surtos de doenças associadas com água potável em 17 estados e territórios dos Estados Unidos, estimando que 17.464 pessoas foram afetadas. Os agentes etiológicos principais foram Giardia lamblia, Cryptosporidium, vírus da Hepatite A, Shigella sonnei e agentes químicos (MOORE et al., 1994).

Segundo ALVAREZ et al. (1990), no Chile a incidência de febre tifóide é muito alta como mostra a ocorrência de 11.533 casos em 1977 e de 6.180 em 1978. Metade dos casos (57,2\%), ocorreu na cidade de Santiago e seus arredores. A água da cidade não é contaminada com Salmonella typhi (ST) ou outros enteropatogênicos mas o rio Mapocho, Zaanjón de la Aguada e outros canais recebem esgoto.

Os surtos de enterites veiculados pela água por Campylobacter spp tem sido documentados em várias partes do mundo nos últimos anos. Na maioria dos casos as doenças estão associadas a águas superficiais não tratadas ou água potável contaminada (JONES et al., 1990).

Em junho de 1987 um surto de enterite aguda aconteceu durante um período de 2 semanas numa pequena comunidade rural de Quebec, Canadá, onde o suprimento de água potável não era filtrado e nem fervido, tendo Campylobacter jejuni sido isolada em 6 pacientes (ALARY \& NADEAU, 1990). 
Um surto de enterite por Campylobacter ocorreu em um acampamento moderno e centro de convenções perto de Christchurch, Nova Zelândia, nos meses de agosto-setembro de 1990 , no qual foi relatado que 44 pessoas desenvolveram sintomas gastrointestinais e nas amostras de fezes de 11 das 14 pessoas sintomáticas detectou-se $C$. jejuni, definindo-se o caso como enterite por Campylobacter. A água do acampamento era obtida de 3 nascentes no local e não era clorada e nem filtrada antes do uso (STEHRGREEN et al.,1991).

De acordo com MILLSON et al. (1991) um grande surto de gastroenterite por Compylobacter jejuni atribuido à contaminação de sistema municipal de água não clorada foi investigado em Toronto, Canadá, onde 241 casos suspeitos foram documentados.

Durante a epidemia de cólera em Mali em 1984, 1.793 casos e 406 mortes (23\%) foram relatados. Uma das causas foi identificada como sendo a água de um poço utilizada para consumo humano (TAUXE et al., 1988).

No início de 1991 a cólera chegou à América do Sul pela primeira vez neste século, penetrando através do Peru, onde em quatro meses foram contaminadas 177.000 pessoas com 1.300 mortes seguindo-se o Equador com 7.000 doentes e 55 mortes, a Colombia com 180 doentes e 4 mortes, o Chile com 28 doentes, o Brasil com 7 doentes e a Argentina com 1 doente (NEVES, 1991).

Segundo o jornal O Estado de São Paulo, de julho de 1992 o Ministério da Saúde registrou mais de 871 casos confirmados de cólera, totalizando 15.240 ocorrências 
em todo o país. O nordeste foi responsável por 13 óbitos registrados. No total, 196 pessoas morreram vítimas da doença naquele ano (SAÚDE, 1992).

Entre 1 de janeiro e 31 de julho de 1992 a cólera epidêmica causou 548 casos notificados (uma incidência de cerca de 8 casos por 100 habitantes), em Riohacha, Colombia. O controle dos estudos de casos revelou uma associação entre a cólera e a água de torneira não fervida e também entre cólera e a limitada disponibilidade de água dentro de casa (CARDENAS et al., 1993).

Alguns microrganismos que são transmitidos pela rota fecal-oral têm potencial para causar infecção pela ingestão de água contaminada. Muitos são excretados por humanos infectados, mas alguns têm origem animal ou ainda ambiental (DADSWELL, 1990).

À bacteriologia da água interessa muito pouco a flora normal, dando-se maiores atenções ao estudo da flora invasora (sob ponto de vista sanitário), que está relacionado com o bem estar humano (MARMO \& JOLY, 1964a e b).

Os microbiologistas não dispõem de técnicas confiáveis que permitam por em manifesto a presença na água de certos agentes patogênicos transmitidos por esta via, como ocorre com o vírus da hepatite infecciosa. Para outras infecções contraídas pelo consumo de alimento e água de beber, tais como a Shigelose, os métodos de laboratório não oferecem suficiente confiança, especialmente quando os agentes patógenos estão em número escasso ou se encontram distribuidos de modo desigual. Nos casos em que se conta com métodos sensíveis, alguns laboratórios podem não dispor das facilidades e capacidades 
técnicas precisas para levar a cabo estas provas. Tais dificuldades tem determinado a ampla utilização de grupos (ou espécies) de microrganismos, cuja enumeração e contagem se realizam com maior facilidade e cuja presença (em determinado número) indica que estes produtos estiveram expostos à condições que puderam introduzir organismos perigosos e/ou permitido a multiplicação de espécies infecciosas ou toxigênicas.Os grupos ou espécies utilizadas com estes fins se denominam microrganismos indicadores (ICMSF,1980). Assim, a análise da água para consumo humano é conduzida primeiramente visando avaliar a potabilidade e determinar o curso de ação para a proteção da população contra as doenças, onde o método de análise indica o grau de contaminação da água com resíduos de humanos e animais, ou seja, baseia-se nos indicadores de contaminação fecal (LAVOIE, 1983).

Os seguintes grupos microbianos têm sido empregados como indicadores higiênico-sanitários ou de contaminação fecal: coliforme total, coliforme fecal, Enterococcus (ICMSF, 1980; LAVOIE, 1983; HAGLER \& MENDONÇA-HAGLER, 1988; APHA, 1989; CETESB, 1991; VERTONI, 1992; LEE \& COLE, 1994). A presença desses indicadores não constitui uma conotação direta da presença de um patógeno, e sim implica unicamente que há um certo risco de que o mesmo poderá estar presente.

Para as águas se tomarem veiculadoras de agentes patogênicos, há necessidade da existência de focos de organismos oriundos de doentes ou às vêzes de portadores assintomáticos, eliminando esses microrganismos com as fezes, propagando enfermidades pelas águas que vão ser consumidas sem tratamento adequado (ICMSF, 1980). 
Mesmo sendo vários os grupos microbianos selecionados como eventuais indicadores da contaminação fecal, sabe-se que nenhum deles preenche os requisitos necessários de um indicador ideal, que resumidamente seriam :

a) habitat exclusivo no trato intestinal de animais e, portanto, idêntico ao dos enteropatógenos cuja presença eles devem indicar;

b) não se multiplicar em outros ambientes, que não o trato intestinal, por tempo idêntico ao dos enteropatógenos;

c) sobreviver em outros ambientes, que não o trato intestinal, por tempo idêntico ao dos enteropatógenos;

d) ter a sua detecção fácil pela ocorrência nos alimentos/água em números relativamente elevados e superior ao dos enteropatógenos;

e) contar com a existência de técnicas rápidas, simples e precisas para sua detecção e/ou contagem (VERTONI,1992).

Vários pesquisadores vem definindo as propriedades do organismo indicador ideal. Haviam dois aspectos em comum entre esses pesquisadores quando definiram os organismos indicadores: poder ocorrer nas fezes em número maior do que os patógenos e que eles não deveriam ser capazes de proliferarem na água (TOBIN \& SMITH, 1989).

Segundo a CETESB (1991), não existe um indicador ideal que reuna todos esses requisitos, sendo que os microrganismos ou grupos de microrganismos utilizados para 
essa finalidade apresentam vantagens e limitações que devem ser consideradas para sua aplicação.

\subsection{Principais Indicadores}

\subsubsection{Bactérias do Grupo Coliforme}

Desde o início da bacteriologia sanitária - marcada pela observação de Escherich, em 1885, de que o Bacillus coli (Escherichia coli) poderia ser usado como um indicador de contaminação fecal da água - as bactérias do grupo coliforme têm sido extensivamente utilizadas na avaliação da qualidade das águas, sendo até hoje o parâmetro microbiológico básico incluído nas legislações relativas a águas para consumo humano (ALVES et al., 1991).

Tem havido controvérsias sobre o significado do grupo coliforme como indicador de poluição fecal, devido a vários relatos sobre surtos de doenças de veiculação hídrica, principalmente Salmoneloses, em comunidades onde a água era considerada adequadamente protegida, pois, com base nos resultados de análises convencionais, atendiam aos padrões para coliformes (MARTINS et al., 1988).

HIRAISHI \& HORIE (1982), afirmam que as bactérias coliformes estão bem estabelecidas como indicadores de perigosas contaminações fecais de água e alimentos. Entretanto, a significância sanitária de coliformes não relacionados à fontes fecais foi e 
ainda é de grande importância, com muito interesse sendo dirigido à sua identidade e patogenicidade.

Dutka $^{1}$ (1976) citado por TOBIN \& SMITH (1989) desafiou o uso de coliforme como um índice na qualidade da água, observando que o mesmo conceito sobre coliforme vem sendo usado por mais de 50 anos e que apesar dos avanços tecnológicos e teóricos sobre microbiologia e saúde, o uso de coliformes como indicadores é inquestionável e os avanços nas pesquisas não foram colocados em prática. Geralmente falta ou inadequação são reconhecidas, porém a contagem dos coliformes ainda vem sendo usada como parâmetro de maior relevância nos novos padrões; também cita que é improvável que sugestões para mudança dos procedimentos atuais possam ser favoravelmente bem recebidas, já que eles encontram-se amplamente adotados.

As bactérias do grupo coliforme constituem o indicador de contaminação fecal mais utilizado em todo o mundo, sendo empregadas como o parâmetro microbiológico básico na definição de padrões para monitoramento da qualidade das águas destinadas ao consumo humano, bem como para caracterização e avaliação da qualidade das águas em geral (CETESB, 1991).

O grupo coliforme inclui as bactérias aeróbias e anaeróbias facultativas em forma de bastonetes, Gram negativas, não formadoras de esporos e que fermentam a lactose com formação de ácido e gás em 24-48h a $35^{\circ} \mathrm{C}$ (MEHLMAN, 1984; FIGUEIREDO,

${ }^{1}$ DUTKA, B.J. Coliforms are an inadequate index of water quality. J. Env. Health, Denver, 36: 39, 1976. 
1991; CETESB, 1991; FRAZIER \& WESTHOFF, 1993). Neste grupo são incluídos os gêneros Escherichia, Citrobacter, Enterobacter e Klebsiella, da família Enterobacteriaceae (VERTONI, 1992).

A Organização Mundial de Saúde apresenta uma definição mais completa, segundo a qual são incluídos no grupo coliforme todos os bacilos Gram negativos, aeróbios ou anaeróbios facultativos, não formadores de esporos, oxidase-negativos, capazes de crescer na presença de sais biliares ou outros compostos ativos de superfície com propriedades similares de inibição de crescimento, e que fermentam a lactose com produção de aldeído, ácido e gás a $35^{\circ} \mathrm{C}$ em $24-48 \mathrm{~h}$.

Uma percentagem elevadíssima - cerca de 95\% - dos coliformes existentes nas fezes humanas e de outros animais é de E.coli. De estudos realizados ficou estabelecido que as fezes do homem e dos animais de sangue quente são riquíssimas em coliformes e que estas bactérias usualmente não existem em águas não poluídas. Alguns membros do grupo coliforme podem ocorrer, às vezes com relativa abundância, no solo e mesmo em plantas, mas, ainda assim, as águas não poluídas praticamente não apresentam estas bactérias (CETESB, 1991).

Uma grande vantagem dos coliformes como índice de poluição fecal é o fato bem estabelecido de que a sua presença na água pode apresentar com o tempo, decréscimo no número total praticamente igual ao das bactérias patogênicas intestinais. Os coliformes são facilmente isolados da água e identificados; as técnicas bacteriológicas para 
revelá-los são simples, além de rápidas e econômicas, o que permite sua aplicação em exames rotineiros para avaliação da qualidade bacteriológica da água (CETESB, 1991).

O exame completo da qualidade da água envolve quatro linhas de investigação: físico, química, biológica e bacteriológica. Cada uma é essencial e fornece informações que não seriam obtidas de outra forma. $\mathrm{O}$ exame bacteriológico é o meio mais sensível de detectar poluição potencialmente mais perigosa (FERESU \& SICKLE,1990).

Em relação aos métodos oficialmente aceitos em nosso país para quantificação dos coliformes em águas, incluem-se a técnica de tubos múltiplos e a de membrana filtrante, segundo metodologia descrita no "Standard Methods for the Examination of Water and Wastewater" (ALVES et al., 1991).

As vantagens do uso da quantificação dos coliformes em águas são as seguintes:

a) encontram-se normalmente no intestino do homem e de animais de sangue quente;

b) são eliminadas em grande número nas fezes (cerca de $3,0 \times 10^{8}$ por grama);

c) devido à prevalência do grupo coliforme, no esgoto, eles podem ser prontamente quantificados na água poluída recentemente por material fecal, através de métodos laboratoriais simples;

d) ausência de coliformes é prova de uma água bacteriologicamente potável. 
Em contrapartida as limitações são as seguintes:

a) alguns dos componentes do grupo coliforme não são de origem exclusivamente fecal, podendo ser encontrados no solo e em vegetais (Citrobacter, Enterobacter e Klebsiella);

b) algumas espécies desse grupo podem se multiplicar em águas poluídas, com elevado teor nutritivo; e

c) os testes, para detecção de coliformes são sujeitos a interferências devido a outros tipos de bactérias; resultados falsos-negativos podem ocorrer quando espécies de Pseudomonas estão presentes, e resultados falsos-positivos também podem ocorrer devido à ação sinérgica de outras bactérias.

Como o grupo dos coliformes totais inclui gêneros que não são de origem exclusivamente fecal, isto limita sua aplicação como indicador de contaminação fecal. $\mathbf{O}$ reconhecimento deste fato levou ao desenvolvimento de métodos para a enumeração de um sub-grupo dos coliformes, os quais são diferenciados dos coliformes totais pela sua capacidade de fermentar a lactose em temperatura elevada $\left(44,5^{\circ} \mathrm{C}\right)$, constituindo-se esse sub-grupo o dos coliformes fecais.

Embora a utilização dos coliformes fecais, em substituição aos totais, tenha determinado uma melhoria significativa na detecção da contaminação de origem fecal, logo se tornou evidente a existência de outros coliformes termotolerantes além da Escherichia coli (principalmente Klebsiella), os quais, por não serem de origem exclusivamente fecal, comprometiam a especificidade deste sub-grupo para a finalidade proposta. Em decorrência 
disto, as tendências atuais se direcionam para a detecção específica de $E$.coli, que é o único componente do grupo coliforme de origem exclusivamente fecal (CETESB, 1991).

Segundo a APHA (1971), a diferenciação entre o grupo coliforme e os coliformes fecais tem limitado valor na avaliação da qualidade da água para o consumo humano, porque a presença de ambos os tipos de bactérias coliformes traduz uma água insatisfatória e não segura.

BURTON JR et al. (1987), pesquisaram a sobrevivência de 4 bactérias patogênicas fora do trato intestinal: Pseudomonas aeruginosa, Salmonella newport, Escherichia coli e Klebsiella pneumoniae e chegaram aos seguintes resultados : a E. coli sobrevive mais tempo do que $S$. newport e $P$. aeruginosa e que $K$.pneumoniae tende a sobreviver mais tempo do que a $E$. coli. Os autores questionam o uso de $E$. coli como indicador de poluição fecal, porque estudos comprovam que ela morre mais rápido que Salmonella spp. e por isso não é um indicador adequado para a presença deste patógeno. FLINT, 1987, cita também vários estudos feitos em relação a sobrevivência da $E$. coli em águas. Na maioria deles a E.coli desaparece rapidamente por causa da influência da temperatura, sedimentação ou efeitos bactericidas da luz ultra violeta, ou ainda o que é mais provável da combinação destes e de outros fatores.

É importante lembrar que além da E.coli ser a mais importante indicadora de contaminação fecal, também foram caracterizadas linhagens enterotoxigênicas dessa espécie (GALLO, 1992). 
Também é importante salientar que muitas linhagens de $E$. coli carregam fatores resistentes (fatores $\mathrm{R}$ ) que determinam resistência à antibióticos e podem ser transmitidos entre elas mesmas ou à outras bactérias. $\mathrm{O}$ crescente uso de antibióticos foi identificado como o maior fator que contribuiu para o crescimento da incidência de resistência à antibióticos entre essas bactérias (ANTAI, 1987). Também, há linhagens de E. coli que produzem enterotoxinas e contém outros fatores de virulência, incluindo invasividade e fatores de colonização, sendo as mesmas causadoras de doenças diarréicas, e também a maior causa de infecção do trato urinário e infecçoes hospitalares incluindo septicemia e meningites (HOLT et al., 1994). Daí toda a importância da detecção específica da E.coli.

\subsubsection{Enterococcus}

Embora o reconhecimento dos estreptococos fecais como indicadores de contaminação fecal remonte ao início do século, este grupo de bactérias não teve uma aplicação mais generalizada para essa finalidade basicamente por duas razões. Em primeiro lugar, as bactérias do grupo coliforme já vinham sendo amplamente utilizadas como indicadores, considerando-se ser mais fácil a sua enumeração e também por estarem presentes em maior quantidade nas fezes, esgotos e águas poluídas. Em segundo lugar, havia alguma confusão quanto à identidade dos estreptococos fecais, particularmente no que se referia à sua distribuição ecológica, sendo que os estreptococos, que podem ser 
encontrados nas fezes humanas e de outros animais, eram referidos ora como enterococos, ora como estreptococos fecais,e, mais recentemente, como estreptococos do grupo D (CETESB, 1991).

A classificação dos enterococos é baseada primariamente em suas características sorológicas e secundariamente em suas características fisiológicas (HARTMAN \& DEIBEL, 1984).

Incluem-se no grupo D de Lancefield do gênero Streptococcus, as espécies S.faecalis, S.faecium, S.bovis e S. equinus, que são caracterizadas por sorologia e referidas como estreptococos fecais ou enterococos, sendo que muitos autores utilizam esta última denominação, apenas para caracterizar as espécies S.faecalis e $S$. faecium (VERTONI, 1992).

Muito se tem escrito sobre a adequação dos enterococos e sobre o amplo grupo D de Lancefield de estreptococos como indicadores de contaminação fecal. O grupo D inclui, além dos enterococos ( $\boldsymbol{S}$. faecalis e $S$. faecium), estreptococos menos resistentes ao calor, como $S$. bovis e $S$. equinus. O grupo completo se denominou com certa imprecisão com o nome de estreptococos fecais (ICMSF,1980).

O grupo dos estreptococos fecais engloba todas as espécies de estreptococos que ocorrem em grandes quantidades em fezes humanas e de outros animais, apresentando, assim, importância na avaliação da qualidade sanitária de água e esgostos. São as seguintes espécies que o compõem : S. faecalis, $S$. faecium, $S$. avium, $S$. gallinarum, $S$. bovis, $S$. equinus. Todas essas espécies pertencem ao grupo D de Lancefield. Enterococos é um sub- 
grupo dos estreptococos fecais no qual são incluídas as seguintes espécies : S. faecalis, $S$. faecium, S. gallinarum e S. avium (CETESB, 1991).

Os enterococos são diferenciados dos outros estreptococos fecais pela sua habilidade de crescer em pH 9,6 em 6,5\% de cloreto de sódio e às temperaturas de $10 \mathrm{e}$ $45^{\circ} \mathrm{C}$ (CETESB, 1991).

Assim sendo, os enterococos estão incluídos no grupo $\mathrm{D}$, porém não deixam de ser estreptococos fecais. Com isso, todo enterococo é um estreptococo fecal, mas um estreptococo fecal pode não ser necessariamente um enterococo. Evidentemente enterococos, estreptococos do grupo D e estreptococos fecais não são sinônimos (FIGUEIREDO,1991).

Contradizendo essas afirmações HARTMAN \& DEIBEL (1984), dizem que na realidade os estreptococos do grupo D são enterococos, podendo assim ser considerados sinônimos.

O termo enterococos é utilizado de modo geral pelos bacteriologistas desde sua introdução por Thiercelin em 1899. Sherman em 1937 classificou os estreptococos em quatro divisões. Uma das quatro divisōes que estabeleceu foi a divisão enterococos, que constava de quatro espécies : $S$. faecalis, $S$. liquefaciens, $S$. zymogenes e $S$. durans. O nome utilizado para denominar esta divisão, no sentido de Sherman, referia-se a uma taxonomia específica, sem relação com o habitat ou a procedência. Posteriormente Sherman reconheceu que todos os membros da divisão enterococos pertenciam ao grupo sorológico D de Lancefield. 
Depois da clássica revisão de Sherman sobre os estreptococos, numerosos investigadores tem contribuído para a compreensão mais clara das espécies que englobam os enterococos. Em seguida, as espécies foram novamente ordenadas dentro de um esquema taxonômico mais lógico que compreende somente as espécies $S$. fecalis e $S$. faecium e suas respectivas variedades (ICMSF, 1980).

Uma proposta foi feita por Scheleifer \& Kilpper-Balz ${ }^{2}$ (1984) citados por HOLT et al. (1994), para transferir os estreptococos que há muito tinham sido referidos informalmente como enterococos para o gênero separado Enterococcus. Nesta publicação, $S$. faecalis e $S$. faecium foram transferidos para o novo gênero como $E$. faecalis e $E$. faecium, respectivamente. Em seguida $S$. avium e $S$. gallinarum foram transferidos por Collins et al. ${ }^{3}$ (1984), citados por HOLT et al. (1994) para E. avium e E. gallinarum. Novas espécies e sub-espécies de estreptococos foram estabelecidas por outros pesquisadores como pertencentes ao gênero Enterococcus (ex: E. durans, E. casseliflavus e $E$. malodoratus). Um grande número de espécies recentemente descritas tem sido acrescentadas ao gênero Enterococcus.

${ }^{2}$ SCHLEIFER, K.H. \& KILPPER-BÄLZ, R. Transfer of Streptococcus faecal is and Streptococcus faecium to the genus Enterococcus nom. rev. as Enterococcus faecal is comb. nov. and Enterococcus faecium comb. nov. International Journal of Systematic Bacteriology, Washington, 34(1): 31-34. 1984 .

${ }^{3}$ COLLINS, M.D.; JONES, D.; FARROW, J.A.E.; KILPPER-BÄLZ, R.; SCHLEIFER, K.H. Enterococcus avium nom. rev., comb. nov.; E. casseliflavus nom. rev., comb. nov.; E. durans nom. rev.; comb. nov.; E. gall inarum comb. nov.; and $E$. malodoratus sp. nov. International Journal of Systematic Bacteriology, Washington, 34(2): 220-23. 1984. 
Os Enterococcus possuem as seguintes características morfológicas e fisiológicas: são cocos, Gram positivos, geralmente ocorrendo aos pares ou em cadeias curtas; apresentam-se como células esféricas ou ovóides medindo 0,6 - 2,0 X 0,6 - 2,5 $\mu \mathrm{m}$; não formam endosporos; algumas vezes são móveis; são anaeróbios facultativos; quimiorganotróficos; com metabolismo fermentativo onde uma ampla variedade de carboidratos são fermentados com produção principalmente de L-(+)-ácido lático; não produzem gás; seus requerimentos nutricionais são complexos; são catalase negativos; crescem tanto a $10^{\circ} \mathrm{C}$ como a $45^{\circ} \mathrm{C}$ (ótima $37^{\circ} \mathrm{C}$ ), e, em pH 9,6 com 6,5\% de $\mathrm{NaCl}$ e com $40 \%$ de bile; raramente reduzem nitrato; geralmente fermentam a lactose (HOLT et al, 1994).

Ocorrem amplamente no meio ambiente, particularmente em fezes de vertebrados, algumas vezes causando infecção piogênica (HOLT et al, 1994).

Esses cocos são resistentes à desidratação, à ação de desinfetantes e às flutuações de temperatura (VERTONI,1992).

São sensíveis a cloração, sendo destruidos em 15 seg com 10ppm de cloro a pH 5,8 (FIGUEIREDO, 1991).

As características básicas que confirmam sua presença, incluem a capacidade destes organismos de hidrolisarem a esculina e crescerem, tanto à temperatura de $45^{\circ} \mathrm{C}$ como na presença de sais biliares na concentração de 40\% (CETESB,1991).

Segundo MARTINS et al. (1984), o interesse em coliformes fecais (CF) e estreptococos fecais (EF) como os mais confiáveis indicadores da contaminação de águas 
vem aumentando. Estes dois grupos de indicadores são de interesse quando aplicados juntos, onde a proporção entre a densidade dessas bactérias na amostra, informa quanto à origem da poluição fecal. Essa relação (CF/EF) foi proposta por Geldreich \& Kenner (1969) (POURCHER et al., 1991) e segundo os autores a relação acima de 4 sugere contaminação humana e na relação abaixo de 0,7 uma contaminação animal.

Estes valores têm sido questionados devido a variedade da taxa de sobrevivência de espécies do grupo de estreptococos fecais. S. bovis e $S$. equinus morrem rapidamente expostos em ambientes aquáticos; já $S$.faecalis e $S$. faecium tendem a sobreviver mais. Além disso a desinfecção das águas tem efeito significativo nạ proporção desses indicadores, a qual pode resultar em conclusões erradas a respeito de fontes de contaminação. Por estes motivos a proporção $\mathrm{CF} / \mathrm{EF}$ não poderia ser recomendada, e não deveria ser usada como um meio para diferenciação das fontes de poluição humana e animal (APHA, 1989).

POURCHER et al. (1991), também questionaram esta relação CF/EF para distinguir a origem animal ou humana da poluição fecal após fazer contagens de E.coli, Enterococcus e Estreptococos fecais em água de esgoto urbano, em fezes de origem humana e animal e constatar que $E$. coli foi mais numerosa que os estreptococos fecais e Enterococcus em mais de $80 \%$ das amostras sem se importar com sua origem.

Assim como para coliformes, há também dois métodos padrões para análise de Enterococcus: a técnica de tubos múltiplos e a técnica de membrana filtrante. 
As vantagens do uso da quantificação dos Enterococcus em águas são as seguintes:

a) o habitat normal destas bactérias é o trato intestinal do homem e de outros animais homeotérmicos;

b) normalmente não ocorrem em águas e solos de áreas não poluídas, sendo que poucas incidências estão relacionadas diretamente a animais de vida selvagem ou à drenagem de solos por enxurradas;

c) embora possam persistir por longos períodos em águas com alto teor eletrolítico, geralmente não se multiplicam na água, sendo sua presença indicativa de contaminação fecal recente;

d) estudos comparativos, relativos à resistência de vários indicadores, patógenos e vírus, a diferentes processos de tratamento de esgoto, tem demonstrado que a remoção de estreptococos fecais é consideravelmente menor que a de coliformes fecais, sendo, deste modo, mais estritamente relacionada à sobrevivência de vírus; e

e) a identificação dos estreptococos fecais a nível de espécie pode fornecer informações sobre a origem da poluição fecal (humana ou animal).

Em contrapartida as limitações são as seguintes:

a) nesse grupo são incluídos alguns estreptococos de limitada significação sanitária, cujo habitat não é restrito ao intestino do homem e outros animais de sangue quente, podendo ocorrer associados à vegetação e a certos tipos de solos, como o Streptococcus mitis e o $S$. salivarius (FIGUEIREDO, 1991). 


\subsection{Padrões Bacteriológicos de Qualidade de Água}

Os padrões que determinam a qualidade da água variam conforme as condições de cada país, e, dentro de um mesmo país, as autoridades competentes modificam os padrões e parâmetros conforme as condições regionais.

No presente trabalho, os padrões utilizados para a avaliação da qualidade da água foram aqueles estabelecidos pela legislação brasileira federal, estadual e pela internacional (OMS), os quais encontram-se a seguir relacionados (CETESB, 1991).

A Portaria 56 BSB do Ministério da Saúde de 14 de março de 1977 Brasil, estipula que quando a técnica do exame bacteriológico for a do processo de tubos múltiplos, não mais que $10 \%$ de todas as porções de $10 \mathrm{ml}$ examinadas deverão revelar a presença de germes do grupo coliforme.

Eventualmente, 3 ou mais de 5 porções padrão componentes de uma amostra padrão (conjunto de 5 porções de $10 \mathrm{ml}$ de um mesmo frasco de amostra), poderão conter germes do grupo coliformes, desde que isso não ocorra em amostras consecutivas e em mais de $5 \%$ do total das amostras examinadas.

As Normas Técnicas de Alimentos e Bebidas - NTA 60 - Decreto $\mathrm{N}^{\circ}$ 12.486 de 20 de outubro de 1978 - Estado de São Paulo, estabelece ausência de bactérias do grupo coliforme em $100 \mathrm{ml}$ para águas de consumo alimentar. 
A Resolução N $^{\circ} 20$ do Conselho Nacional do Meio Ambiente (CONAMA) de 18 de junho de 1986 estabelece ausência de coliformes totais em qualquer amostra para águas destinadas ao abastecimento doméstico sem prévia desinfecção.

A Portaria N 36 do Ministério da Saúde de 19 de janeiro de 1990 - Brasil, estipula que para águas de nascentes, 95\% das amostras coletadas devem apresentar ausência de coliformes totais em $100 \mathrm{ml}$ e nos $5 \%$ das amostras restantes analisadas serão toleradas até 10 coliformes totais em $100 \mathrm{ml}$ desde que essa contaminação não ocorra em duas amostras consecutivas analisadas.

Os Padrões Internacionais da OMS para Águas Potáveis que se referem a qualidade bacteriológica para águas não canalizadas (poços, fontes) estabelece ausência de coliformes fecais em $100 \mathrm{ml}$. Não devem ocorrer frequentemente mais de 10 coliformes totais.

O uso dos indicadores de contaminação fecal (coliformes e Enterococcus) foi questionado por vários autores (MARTINS et al., 1984 e 1988; RIVILLA \& GONZALES, 1988), mas quando apropriadamente utilizada, é uma técnica que demonstra o grau de poluição e a qualidade higiênica da água.

HAHN et al. (1989), sugerem a análise das amostras de água para todas as enterobactérias citando como vantagens: parâmetros exatamente definidos como bastonetes Gram negativos, fermentação anaeróbia de glicose a $37^{\circ} \mathrm{C}$ e oxidase negativa (um teste de método simples e rápido, onde poderiam estar incluídas espécies patogênicas como Salmonella, Shigella e Yersinia). 
HAVELAAR \& DUNRING (1988), adaptaram o método de plaqueamento direto para a enumeração de $E$. coli em alimentos para análise de água (Método Anderson Baird-Parker), justificando que o isolamento e a enumeração de $E$. coli por métodos tradicionais requer uma fase de enriquecimento em meio líquido ou filtração por membrana e incubação em meio sólido, ambos seguidos pela subcultura e testes adicionais nas culturas positivas, sendo isso tedioso e com consumo de muito tempo.

HOLMES \& HUMPHRY (1988), sugeriram a identificação da família Enterobacteriaceae com o sistema Minitek (Sistema comercial de identificação com 35 testes) para agilizar as análises.

EDBERG et al. (1989), tentando superar as limitações dos métodos tradicionais defendem um novo método baseado em uma tecnologia para identificar microrganismos através da análise de suas enzimas constitutíveis. Utiliza um substrato hidrolisável como um nutriente de indicador específico para um microrganismo alvo que vai ser enumerado. Os nutrientes indicadores específicos do sistema Colilert orto-nitrofenilB-d-glucuronideo (ONPG) se correspondem com as enzimas constitutivas, que estão sempre presentes nas bactérias e que somente existem nos coliformes e em $E$. coli. As bactérias coliformes contém a enzima constitutiva B-galactosidase, a $E$. coli contém a enzima constitutiva B-glucoronidase. Se existir coliformes na amostra elas metabolizarão os nutrientes indicadores específicos: 4-metil-umbeliferil-ß-d-glucoronídeo (MUG) e ortonitrofenil-B-d-glucuronideo (ONPG) que ao "quebrar-se" produzirão fluorescência. Esta tecnologia foi designada autoanálise porque a mudança de cor é produzida pelo 
microrganismo alvo que cresceu. A tecnologia foi denominada de Autoanálise Colilert sendo rápido e específico para detecção simultânea de coliformes totais e $E$. coli em água para beber.

Com a necessidade de um método sensível, específico e rápido para se avaliar a qualidade bacteriológica da água, JORET et al. (1989), sugerem o uso do método de anticorpos monoclonais (MoAb) para detecção de $E$. coli em água que é feito em menos de três horas através de uma técnica imunofluorescente após pré-concentração da bactéria em filtro de policarbonetos, sendo este método específico para contaminação fecal.

O teste de colifagos, um método simples, rápido e econômico de avaliação da qualidade de água natural e potável, foi descrito por EL-ABAGY \& KAMEL (1989) no Egito. Neste estudo, comparou-se o teste de colifago com o procedimento convencional de coliformes totais e fecais, e os autores concluíram que é um bom método para se avaliar a potabilidade da água, sendo simples, não dispendioso, com resultados em 6 horas e com boa relação com os métodos convencionais, tendo como grande vantagem a rapidez dos resultados.

O teste de coliforme equivalente (CE) foi desenvolvido como uma resposta do problema da não identificação de células estressadas não detectadas nos testes convencionais para coliformes. O objetivo foi desenvolver um indicador mais confiável para coliformes, inclusive coliformes estressados. $\mathrm{O}$ teste $\mathrm{CE}$ mede a densidade de coliformes por correlação da atividade enzímica com o número de células definidas na contagem em placas de culturas puras (NIX \& HOLMES, 1989). Baseando-se nessa correlação as 
amostras do CE serão obtidas diretamente dos filtros cartuchos com volume conhecido e serão incubadas em meio seletivo para coliformes (DIFCO). Durante a incubação a atividade enzímica (dehydrogenase) é diretamente medida através das alterações das cores, as quais são conduzidas pela redução quantitativa da Resazurina, uma tintura redox.

GATTI \& NEVIANE (1993), propõem um meio simples e novo para a identificação de espécies de Enterococcus pela medida da condutibilidade, intitulando-o de sistema Malthus - AT. O crescimento e a atividade metabólica dos microrganismos ocasionará mudanças de condutância e em meio específico servirá para a identificação de Enterococcus.

Existe o reconhecimento sobre a necessidade de um método que permita estimativa rápida da qualidade bacteriológica da água, principalmente em caso de uma emergência como falta de tratamento de água, quebra da linha de trabalho de distribuição, interrupções causadas por desastres, etc. Tais procedimentos rápidos devem ser confiáveis e ter um nível de sensibilidade semelhante aos dos testes padrões rotineiramente usados. O Standard Methods for Examination of Water and Wastewater (APHA, 1989) recomenda o teste de bioluminescência onde é medida a emissão de luz fosforescente pelo teste de luciferase para ATP em células vivas, [o qual baseia-se em uma reação entre a enzima luciferase, a lucifenina (substrato da enzima), íons magnésio e ATP]; o teste do colorímetro para estimativa da densidade total microbiana e o teste de detenção radiométrica para coliforme fecal, que usa um substrato de $\mathrm{C}$ marcado e o $\mathrm{CO}_{2}$ liberado fica preso no papel 
filtro em contato com $\mathrm{Ba}(\mathrm{OH})_{2}$ saturado, sendo analisado por espectrômetro de cintilação líquida. 


\section{MATERIAL E MÉTODOS}

\subsection{Material}

- Frasco para coleta de amostras (erlenmeyer Pyrex com capacidade de 500 $\mathrm{ml})$.

- Frasco para diluição (vidro neutro com tampa de rosca com capacidade de $160 \mathrm{ml}$, com graduação de 90 a $99 \mathrm{ml}$ ).

- Tubos de ensaio (vidro neutro, de $18 \mathrm{~mm}$ X $180 \mathrm{~mm}, 16 \mathrm{~mm}$ por 150 $\mathrm{mm} \mathrm{e} 12 \mathrm{~mm} \mathrm{X} 120 \mathrm{~mm}$ ).

- Tubos de fermentação (tubos de Durham, de $7 \mathrm{~mm} \mathrm{X} 45 \mathrm{~mm}$ e de $5 \mathrm{~mm}$ X $40 \mathrm{~mm}$ ).

- Pipeta tipo Mohr, de $1 \mathrm{ml}, 5 \mathrm{ml}, 10 \mathrm{ml}$.

- Porta-pipetas de aço inoxidável

- Beckers de 1.000 e $2.000 \mathrm{ml}$ para preparo dos meios de cultivo

- Bico de Bunsen.

- Tripé

- Tela de amianto. 
- Algodão hidrófilo

- Alças de inoculação (de níquel-cromo ou platina-irídio com 7 a $8 \mathrm{~cm}$ de comprimento e $0,5 \mathrm{~mm}$ de diâmetro, apresentando um aro de $3 \mathrm{~mm}$ de diâmetro na extremidade, colocadas em cabo de metal (cabo de Kolle).

- Placas de Petri de $10 \times 100 \mathrm{~mm}$.

- Lâminas para microscopia.

Equipamentos

- Balança MICRONAL B600

- Estufa incubadora FANEM mod. 002

- Estufa para esterilização FANEM mod. 315-SE

- Autoclave FABBE mod. 103

- Microscópio BAUSCH \& LOMB

Meios de Cultura Desidratados

- Caldo Lactosado (CL - DIFCO 004-01-5).

- Meio E.C. (DIFCO 0314-01-0).

- Caldo Lactosado com Verde Brilhante Bile 2\% (CLVBB - DIFCO

0014-17-5). 
- Ágar Eosina Azul de Metileno (EMB-agar DIFCO 0076-01-8).

- Ágar nutriente (NA - DIFCO 0001-01-8).

- Caldo Dextrose Azida - CDA (CETESB, 1991).

- Pfizer Seletive Enterococcus - PSE (CETESB, 1991).

\section{Outros Reagentes}

- Solução de tiossulfato de sódio à $1 \%$ para neutralização do cloro.

- Solução de cristal violeta para coloração de Gram.

- Solução de oxalato de amônia para coloração de Gram.

- Solução de lugol a 20\% para coloração de Gram.

- Solução de safranina para coloração de Gram.

- Álcool etílico a 95\% para coloração de Gram.

- Solução de cloridrato de $\mathbf{N}, \mathbf{N}, \mathbf{N}, \mathbf{N}$ - tetrametil-p-fenilenodiamina à $1 \%$ para $o$ teste de oxidase.

- Púrpura de bromocresol.

- Solução de safranina para coloração de esporos.

- Solução de verde malaquita para coloração de esporos. 


\subsection{Metodologia}

\subsubsection{Amostragem}

As amostras de água utilizadas no presente trabalho foram de 8 nascentes (bicas) da cidade de Piracicaba - SP, escolhidas por serem as de maior procura pela população da cidade. A Figura 1, mostra a localização das referidas nascentes.

As amostras foram coletadas de setembro de 1993 a junho de 1994 visando com esse período poder trabalhar com diferenças climáticas quanto a precipitações, temperaturas, etc.; obtendo-se assim um bom material para discutir tais prováveis influências sobre a qualidade bacteriológica da água.

As coletas foram quinzenais, sendo as amostras de água coletadas em erlenmeyers Pyrex de 500ml esterilizados e transportadas imediatamente para o laboratório de Microbiologia de Alimentos do Departamento de Ciência e Tecnologia Agroindustrial da ESALQ/USP, com intervalo de tempo entre coleta e análise inferior a 2 horas.

Para as determinações a seguir adotou-se a metodologia da Companhia de Tecnologia de Saneamento Ambiental - CETESB, que é um órgão nacional e cuja metodologia é um agrupamento de várias metodologias oficiais mundialmente aceitas como: FDA (Food and Drug Administration), APHA e ICMSF. 


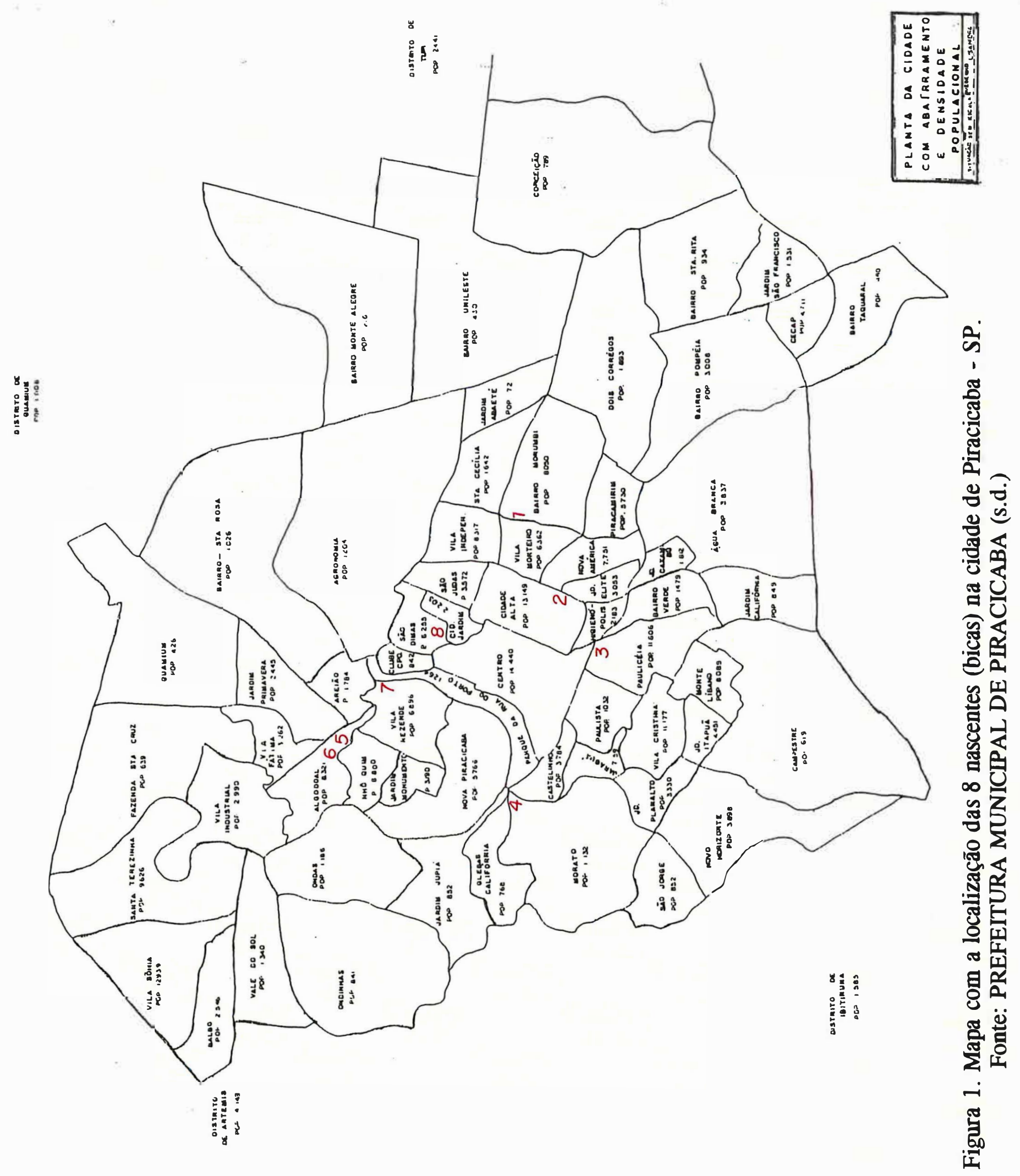




\subsubsection{Determinação de Coliformes Totais e Fecais pela Técnica de Tubos}

\section{Múltiplos}

O exame se processou em duas etapas que se constituíram nos ensaios presuntivo e confirmativo, as quais podem ser visualizadas no esquema geral (Figura 2).

Para o ensaio presuntivo, volumes determinados da amostra de água $(10 \mathrm{ml}$, $1 \mathrm{ml} \mathrm{e} 0,1 \mathrm{ml}$ ) foram inoculados em séries de 5 tubos com caldo lactosado acrescido de púrpura de bromocresol, os quais foram incubados a $35 \pm 0,5^{\circ} \mathrm{C}$, durante $24-48$ horas, ocorrendo um enriquecimento de organismos fermentadores de lactose. A acidificação, com ou sem produção de gás, decorrente da fermentação da lactose contida no meio de cultura empregado nesse ensaio, é prova presuntiva positiva para a presença de bactérias do grupo coliforme.

Para a realização do ensaio confirmativo, todos os tubos com resultado positivo em caldo lactosado com púrpura de bromocresol nas leituras de 24 e $48 \mathrm{~h}$ foram submetidos à confirmação imediatamente após as respectivas leituras, inoculando-os em caldo lactosado com verde brilhante e bile a $2 \%$, para determinação de coliformes totais.

A produção de gás, a partir da fermentação da lactose em CLVBB, com incubação a $35 \pm 0,5^{\circ} \mathrm{C} / 48 \mathrm{~h}$, é prova confirmativa para a presença de bactérias do grupo coliforme. Esta etapa do exame reduz a possibilidade de atividade de bactérias esporuladas e de bactérias Gram-positivas fermentadoras de lactose. 
O ensaio completo incluiu, além da realização dos ensaios presuntivo e confirmativo, o isolamento das culturas de bactérias com resultado positivo no CLVBB em placas de Ágar Eosina Azul de Metileno, para a realização de testes posteriores. Colônias isoladas em ágar EAM foram transferidas para $\mathrm{CL}$ e para ágar nutriente, sendo o crescimento bacteriano neste último meio empregado para realização do teste de oxidase, coloração de Gram e coloração de esporos.

O resultado do teste completo será positivo quando houver produção de gás a partir da fermentação da lactose em CL, for comprovado resultado negativo no teste de oxidase e for demonstrado, por exame microscópico, a presença de bacilos Gram negativos, não esporulados. A realização do teste completo visa eliminar os resultados falsos-positivos, que podem ocorrer no CLVBB devido a ação sinérgica de bactérias.

A densidade de coliformes é expressa como Número Mais Provável (NMP) de coliformes por $100 \mathrm{ml}$, o qual é obtido através de tabelas, em que são dados os limites de confiança de $95 \%$ para cada valor de NMP determinado.

Foi utilizada a tabela de índice de NMP e com limites de confiança de 95\%, utilizando-se inóculos de $10 \mathrm{ml}, 1 \mathrm{ml} \mathrm{e} \mathrm{0,1} \mathrm{ml}$ em séries de 5 tubos (CETESB,1991).

A determinação de coliformes fecais consistiu na transferência de cada cultura com resultado presuntivo positivo (acidificação do meio, com ou sem produção de gás, após 24-48 horas à $35 \pm 0,5^{\circ} \mathrm{C}$ ) para tubos contendo caldo EC, que foram incubados durante $24 \pm 2$ horas à $44,5 \pm 0,2^{\circ} \mathrm{C}$ ) em banho termostático com agitação. 
Tal determinação, baseia-se na habilidade dos coliformes fecais, especialmente a $E$. coli, de fermentar a lactose com produção de gás, em $24 \mathrm{~h}$ a $44,5^{\circ} \mathrm{C}$. 


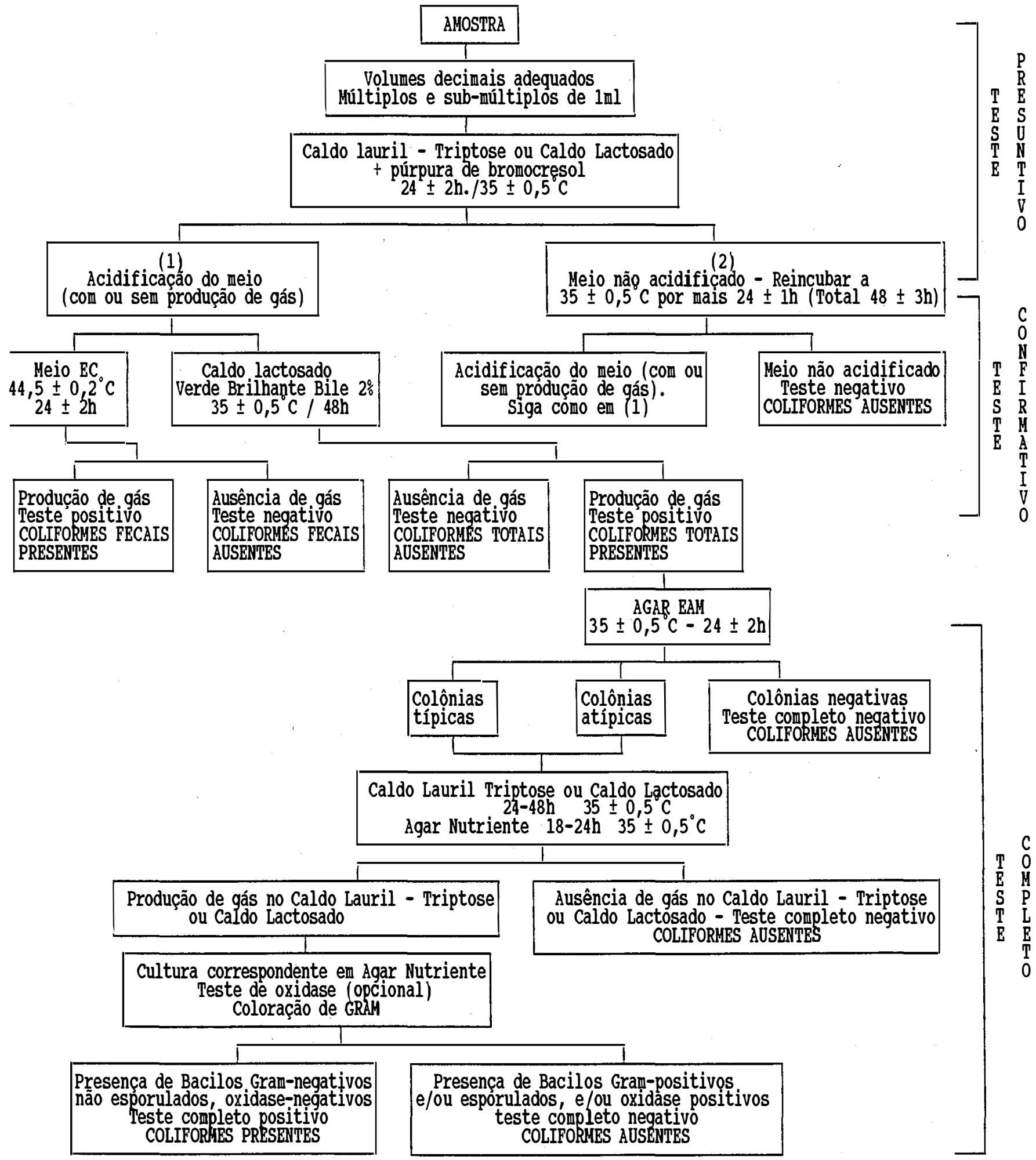

Figura 2. Esquema do procedimento para determinação de Coliformes Fecais (Técnica de Tubos Múltiplos). Fonte: CETESB, 1991. 
As principais reações que ocorrem nos testes para determinação de coliformes totais e fecais pela técnica de tubos múltiplos são:

- Em CL com púrpura de bromocresol : fermentação da lactose, com acidificação do meio, com ou sem produção de gás.

- Em CLVBB e EC: fermentação da lactose com produção de gases (hidrogênio e dióxido de carbono).

- Em EAM: o desenvolvimento de bactérias fermentadoras de lactose possibilita a incorporação do corante (eosina-azul de metileno) existente no meio, sendo que as colônias podem ser descritas como típicas (nucleadas, com ou sem brilho metálico), atípicas (rosas, mucóides, opacas e sem núcleo) ou negativas (todos os outros tipos).

- O teste de oxidase, tem por finalidade evidenciar a presença da citocromo-oxidase, uma enzima oxidativa da cadeia respiratória das bactérias. Esta enzima é necessária para a oxidação do citocromo-c, segundo a seguinte reação:

2 citocromo-c-reduzido $+2 \mathrm{H}^{-}+1 / 2 \mathrm{O}_{2} \stackrel{\text { citocromo-oxidase }}{ } \longrightarrow 2$ citocromo-oxidase-oxidado $+\mathrm{H}_{2} \mathrm{O}$

No teste de oxidase, o citocromo-c, em sua forma oxidada, catalisa a oxidação do tetrametil-p-fenilenodiamina, formando-se uma substância de coloração azul. As bactérias oxidase-negativas (que não possuem a enzima citocromo oxidase) não exibem a formação desse composto azul, quando em contato com o tetrametil-p-fenilenodiamina. 


\subsubsection{Determinação de Enterococcus pela Técnica de Tubos Múltiplos}

O exame se processou em 2 etapas: ensaios presuntivo e confirmativo, que podem ser visualizados no esquema da Figura 3.

O teste presuntivo, consistiu na semeadura de volumes determinados da amostra (10,1 e 0,1 ml) em 3 séries de 5 tubos contendo Caldo Dextrose Azida - CDA (CETESB, 1991), que foram incubados a $35 \pm 0,5^{\circ} \mathrm{C}$ durante 24 horas. A turvação e/ou formação de precipitado no meio é resultado presuntivo positivo para Enterococcus neste ensaio.

Para o teste confirmativo, foi realizada a transferência de cada cultura com resultado presuntivo positivo (turvação e/ou formação de precipitado em CDA) para placas de Petri contendo ágar PSE (Pfizer Selective Enterococcus Agar (CETESB, 1991), sendo a incubação efetuada a $35 \pm 0,5^{\circ} \mathrm{C}$, durante 48 horas. A presença de colônias com coloração castanho-enegrecida, com halo marrom (decorrente da hidrólise da esculina), constitui resultado positivo neste ensaio, confirmando a presença de Enterococcus. 


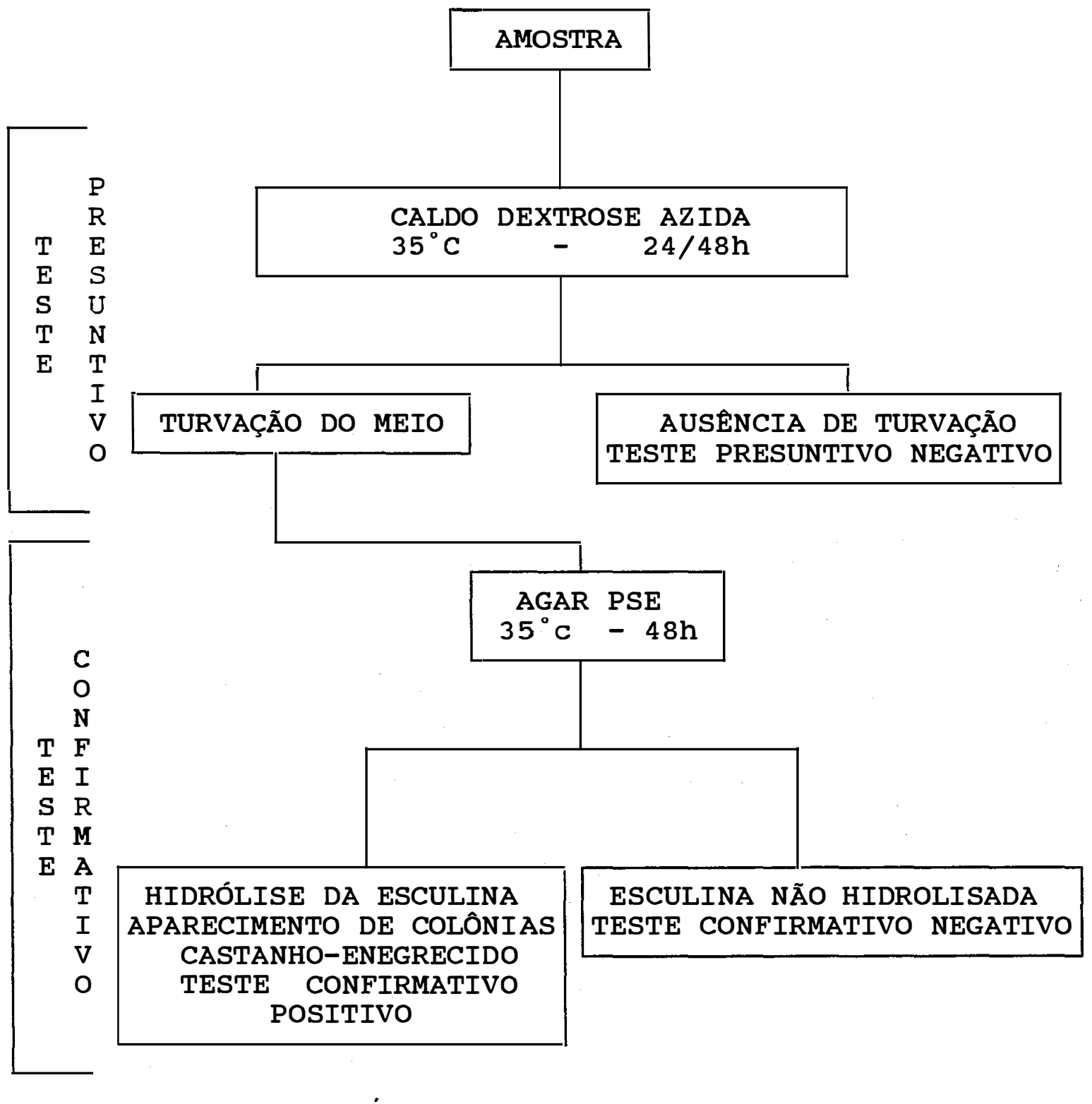

Figura 3. Esquema do procedimento para determinação de Enterococcus (Técnica de Tubos Múltiplos). Fonte: CETESB, 1991. 
As principais reações que ocorrem nos testes para a determinação de Enterococcus pela técnica de tubos múltiplos estão descritas a seguir:

- Em caldo Dextrose Azida: este meio contém os fatores nutrientes requeridos para a maioria das bactérias. A incorporação de azida de sódio inibe o crescimento de bactérias Gram-negativas, devido a inibição do sistema citocromo bacteriano e redução da atividade da catalase. Os cocos Gram-positivos não são afetados por esse inibidor e crescem satisfatoriamente. Os Enterococcus se desenvolvem nesse meio, fermentando a dextrose e sua presença é detectada pela turvação e/ou formação de precipitado no meio.

- Em Agar PSE: os Enterococcus, através de suas enzimas e na presença de água, hidrolisam a esculina contida no meio, havendo a formação de esculetina $(6,7$ dihidroxicumarina), que reage com o íon férrico no meio, formando um complexo castanho enegrecido, difusível no meio, conferindo às colônias típicas essa coloração.

$$
\begin{aligned}
& \text { esculina }+\mathrm{H}_{2} \mathrm{O} \longrightarrow \text { enzimas de Enterococcus } \longrightarrow \text { glicose }+ \text { esculetina } \\
& \text { esculetina }+\mathrm{Fe}_{3} \longrightarrow \text { complexo castanho enegrecido }
\end{aligned}
$$




\section{RESULTADOS E DISCUSSĀO}

Os números mais prováveis (NMP) de coliformes totais, coliformes fecais e Enterococcus encontram-se relacionados nas Tabelas de 2 a 9 e Figuras de 4 a 11 . As condições climáticas nos dias de coleta estão relacionadas na Tabela 10. As Figuras de 12 a 19 apresentam a incidência em porcentagem da contaminação das amostras/nascentes com coliformes totais, coliformes fecais e Enterococcus. 
Tabela 2. Número Mais Provável (NMP) de Coliformes e Enterococcus/100ml de água Nascente 1.

\begin{tabular}{lccc}
\hline Amostra & Coliformes Totais & Coliformes Fecais & Enterococcus \\
\hline 1 & 350 & 13 & 0 \\
2 & 56 & 2 & 49 \\
3 & 2400 & 1,8 & 220 \\
4 & 170 & 4 & 7,8 \\
5 & 120 & 2 & 7,8 \\
6 & 920 & 23 & 23 \\
7 & 34 & 0 & 23 \\
8 & 49 & 2 & 4,5 \\
9 & 48 & 0 & 130 \\
10 & 140 & 23 & 4,5 \\
11 & 40 & 0 & 34 \\
12 & 39 & 0 & 13 \\
13 & 350 & 0 & 220 \\
14 & 540 & 0 & 23 \\
15 & 130 & 0 & 33 \\
16 & 21 & 0 & 170 \\
17 & 26 & 0 & 2 \\
18 & 350 & 0 & 7,8 \\
& & & \\
\hline
\end{tabular}

De acordo com a legislação federal e estadual (Portaria 56 BSB do Ministério da Saúde, de 14 de março de 1977; Portaria n⿳ 36, do Ministério da Saúde, de 19 de janeiro de 1990; NTA 60 - Decreto $\mathrm{N}^{\circ} 12.486$ de 20 de outubro de 1978 do Estado de São Paulo e Resolução N $^{\circ} 20$ do Conselho Nacional do Meio Ambiente - CONAMA, de 18 de junho de 1986) e os padrões internacionais da OMS referentes a qualidade bacteriológica para águas potáveis, vê-se que a água desta nascente está fora dos padrões referidos e portanto imprópria para o consumo humano, uma vez que $100 \%$ das amostras analisadas mostraram-se contaminadas com coliformes totais e $44,44 \%$ das amostras coletadas apresentaram-se contaminadas com coliformes fecais. 
Tabela 3. Número Mais Provável (NMP) de Coliformes e Enterococcus/100ml de água Nascente 2.

\begin{tabular}{lccc}
\hline Amostra & Coliformes Totais & Coliformes Fecais & Enterococcus \\
\hline 1 & 920 & 0 & 0 \\
2 & 160 & 0 & 170 \\
3 & $>2400$ & 40 & 130 \\
4 & $>2400$ & 6,1 & 240 \\
5 & 32 & 9,3 & 240 \\
6 & 54 & 32 & 23 \\
7 & 32 & 4 & 23 \\
8 & 25 & 1,8 & 22 \\
9 & 22 & 2 & 2400 \\
10 & 240 & 1,8 & 6,8 \\
11 & 17 & 4 & 70 \\
12 & 430 & 7,8 & 4,5 \\
13 & 920 & 0 & 4,5 \\
14 & 1600 & 0 & 350 \\
15 & 280 & 0 & 11 \\
16 & 350 & 1,8 & 23 \\
17 & 540 & 0 & 2 \\
18 & 240 & 0 & 23 \\
\hline
\end{tabular}

De acordo com a legislação citada anteriormente, conclui-se que a água desta nascente está fora dos padrões e, portanto, imprópria para o consumo humano, uma vez que $100 \%$ das amostras coletadas apresentaram-se contaminadas com coliformes totais e $61,11 \%$ com coliformes fecais. 
Tabela 4. Número Mais Provável (NMP) de Coliformes e Enterococcus/100ml de água Nascente 3.

\begin{tabular}{lccc}
\hline Amostra & Coliformes Totais & Coliformes Fecais & Enterocuccus \\
\hline 1 & 0 & 0 & 0 \\
2 & 0 & 0 & 0 \\
3 & 0 & 0 & 0 \\
4 & 0 & 0 & 0 \\
5 & 0 & 0 & 0 \\
6 & 0 & 0 & 0 \\
7 & 0 & 0 & 0 \\
8 & 0 & 0 & 0 \\
9 & 0 & 0 & 0 \\
10 & 8 & 0 & 0 \\
11 & 0 & 0 & 0 \\
12 & 0 & 0 & 0 \\
13 & 0 & 0 & 0 \\
14 & 0 & 0 & 0 \\
15 & 0 & 0 & 0 \\
16 & 4 & 0 & 0 \\
17 & 0 & 0 & 0 \\
18 & 0 & 0 & 0 \\
\hline
\end{tabular}

De acordo com a legislação citada anteriormente, nota-se que a água desta nascente se enquadra nos referidos padrões de potabilidade, sendo, portanto, considerada própria ao consumo humano. 
Tabela 5. Número Mais Provável (NMP) de Coliformes e Enterococcus $/ 100 \mathrm{ml}$ de água Nascente 4.

\begin{tabular}{cccc}
\hline Amostra & Coliformes Totais & Coliformes Fecais & Enterococcus \\
\hline 1 & 7,8 & 0 & 0 \\
2 & 170 & 0 & 14 \\
3 & 11 & 7,8 & 0 \\
4 & 0 & 0 & 0 \\
5 & 4 & 0 & 0 \\
6 & 6,8 & 0 & 4,5 \\
7 & 47 & 0 & 7,8 \\
8 & 4 & 0 & 0 \\
9 & 27 & 0 & 7,8 \\
10 & 23 & 0 & 0 \\
11 & 4,5 & 0 & 0 \\
12 & 2 & 0 & 0 \\
13 & 7,8 & 0 & 0 \\
14 & 2 & 0 & 7,8 \\
15 & 13 & 0 & 0 \\
16 & 95 & 0 & 7,8 \\
17 & 13 & 0 & 0 \\
18 & 13 & 0 & 0 \\
\hline
\end{tabular}

Analisando-se isoladamente os resultados obtidos poder-se-ia erroneamente considerar as amostras $1,5,6,8,11,12,13$ e 14, embora suspeitas, não efetivamente impróprias ao consumo humano uma vez que apresentaram o número de coliformes totais inferior a 10/100 ml e ausência de coliformes fecais.

Porém, ao analisarmos todos os resultados obtidos, o que nos fornece um histórico do manancial, através de análises sistemáticas, conclui-se que a água desta nascente é imprópria ao consumo humano, de acordo com a legislação citada anteriormente. 
Das 18 coletas efetuadas, somente a de número 4, apresentou-se como própria ao consumo humano.

Tabela 6. Número Mais Provável (NMP) de Coliformes e Enterococcus $/ 100 \mathrm{ml}$ de água Nascente 5.

\begin{tabular}{lccc}
\hline Amostra & Coliformes Totais & Coliformes Fecais & Enterococcus \\
\hline 1 & 27 & 0 & 0 \\
2 & 38 & 0 & 9,3 \\
3 & 240 & 14 & 49 \\
4 & 240 & 0 & 0 \\
5 & 11 & 0 & 11 \\
6 & 49 & 17 & 22 \\
7 & 70 & 0 & 8,3 \\
8 & 70 & 2 & 0 \\
9 & 33 & 2 & 130 \\
10 & 220 & 0 & 2 \\
11 & 13 & 0 & 0 \\
12 & 4,5 & 0 & 11 \\
13 & 23 & 2 & 0 \\
14 & 26 & 0 & 49 \\
15 & 13 & 0 & 0 \\
16 & 11 & 0 & 4,5 \\
17 & 23 & 0 & 4 \\
18 & 350 & 0 & 0 \\
\hline
\end{tabular}

De acordo com a legislação já mencionada, nota-se que a água desta nascente está fora dos padrões e portanto imprópria para o consumo humano, uma vez que $100 \%$ das amostras coletadas apresentaram-se contaminadas com coliformes totais e $27,77 \%$ com coliformes fecais. 
Tabela 7. Número Mais Provável (NMP) de Coliformes e Enterococcus/100ml de água Nascente 6.

\begin{tabular}{cccc}
\hline Amostra & Coliformes Totais & Coliformes Fecais & Enterococcus \\
\hline 1 & 0 & 0 & 0 \\
2 & 6,8 & 1,8 & 0 \\
3 & 0 & 0 & 2 \\
4 & 2 & 0 & 0 \\
5 & 0 & 0 & 4,5 \\
6 & 11 & 0 & 13 \\
7 & 0 & 0 & 0 \\
8 & 4,5 & 0 & 0 \\
9 & 49 & 0 & 17 \\
10 & 2 & 0 & 0 \\
11 & 2 & 0 & 0 \\
12 & 0 & 0 & 0 \\
13 & 0 & 0 & 0 \\
14 & 0 & 0 & 0 \\
15 & 4 & 4 & 0 \\
16 & 0 & 0 & 0 \\
17 & 0 & 0 & 0 \\
18 & 0 & 0 & 0 \\
\hline
\end{tabular}

Analisando-se isoladamente os resultados obtidos poder-se-ia erroneamente considerar a água, embora suspeita, não efetivamente imprópria ao consumo humano (número de coliformes totais inferior a $10 / 100 \mathrm{ml}$ e ausência de coliformes fecais), nas coletas $4,8,10,11$. As amostras $1,3,5,7,12,13,14,16,17$ e 18, apresentaram-se próprias para o consumo humano. Das amostras analisadas, $44,44 \%$ se mostraram contaminadas com coliformes totais e $11,11 \%$ se mostraram contaminadas com coliformes fecais. 
Assim, ao analisarmos todos os resultados obtidos, o que nos fornece um histórico do manancial, através de análises sistemáticas, conclui-se que a água desta nascente é imprópria ao consumo humano, de acordo com a legislação citada anteriormente.

Tabela 8. Número Mais Provável (NMP) de Coliformes e Enterococcus/100ml de água Nascente 7.

\begin{tabular}{lccc}
\hline Amostra & Coliformes Totais & Coliformes Fecais & Enterococcus \\
\hline 1 & 11 & 5,6 & 0 \\
2 & 110 & 2 & 22 \\
3 & 22 & 13 & 350 \\
4 & 110 & 4,5 & 2 \\
5 & 27 & 9,3 & 2 \\
6 & 9,2 & 4 & 0 \\
7 & 17 & 6,1 & 140 \\
8 & 33 & 7,8 & 2 \\
9 & 49 & 4 & 23 \\
10 & 33 & 24 & 2 \\
11 & 54 & 4,5 & 95 \\
12 & 49 & 0 & 0 \\
13 & 5,6 & 0 & 6,1 \\
14 & 17 & 4 & 7,8 \\
15 & 17 & 0 & 0 \\
16 & 21 & 0 & 9,3 \\
17 & 23 & 0 & 6,8 \\
18 & 31 & 0 & 0 \\
\hline
\end{tabular}

De acordo com a legislação citada anteriormente, vê-se que a água desta nascente está fora dos padrões e portanto imprópria para o consumo humano, uma vez que $100 \%$ das amostras coletadas apresentaram-se contaminadas com coliformes totais e $66,66 \%$ com coliformes fecais. 
Tabela 9. Número Mais Provável (NMP) de Coliformes e Enterococcus $/ 100 \mathrm{ml}$ de água Nascente 8.

\begin{tabular}{lccc}
\hline Amostra & Coliformes Totais & Coliformes Fecais & Enterococcus \\
\hline 1 & 13 & 0 & 0 \\
2 & 13 & 0 & 0 \\
3 & 17 & 0 & 0 \\
4 & 0 & 0 & 0 \\
5 & 11 & 0 & 2 \\
6 & 79 & 17 & 4,5 \\
7 & 11 & 0 & 0 \\
8 & 33 & 0 & 4,5 \\
9 & 45 & 11 & 350 \\
10 & 13 & 0 & 1600 \\
11 & 2 & 0 & 7,8 \\
12 & 7,8 & 0 & 1,8 \\
13 & 2 & 0 & 0 \\
14 & 17 & 0 & 0 \\
15 & 2 & 0 & 0 \\
16 & 0 & 0 & 0 \\
17 & 7,8 & 0 & 0 \\
18 & 1,8 & 0 & 0 \\
\hline
\end{tabular}

Analisando-se isoladamente os resultados obtidos poder-se-ia erroneamente considerar a água, embora suspeita, não efetivamente imprópria ao consumo humano (número de coliformes totais inferior a $10 / 100 \mathrm{ml}$ e ausência de coliformes fecais), nas coletas $11,12,13,15,17$ e 18). As amostras 4 e 16 mostraram-se próprias para o consumo humano. Das amostras analisadas, $\mathbf{8 8 , 8 9 \%}$ se mostraram contaminadas com coliformes totais e $11,11 \%$ se mostraram contaminadas com coliformes fecais.

Portanto, ao analisarmos todos os resultados obtidos, conclui-se que a água desta nascente é imprópria ao consumo humano conforme a legislação citada anteriormente. 
Apesar de não haver padrão para os Enterococcus, os resultados apresentados (Tabelas de 2 a 9) servem como reforço às análises para coliformes, confirmando a não potabilidade para consumo humano, da água de 7 das 8 nascentes analisadas, por apresentarem além das bactérias do grupo coliforme, também bactérias pertencentes ao gênero Enterococcus onde se incluem espécies bacterianas de origem fecal.

Tabela 10. Condições climáticas nos dias de coleta.

\begin{tabular}{cccll}
\hline Coleta & $\begin{array}{c}\text { Horário } \\
\text { da coleta }\end{array}$ & $\begin{array}{c}\text { Temperatura } \\
\text { ambiente }\end{array}$ & $\begin{array}{c}\text { Estação } \\
\text { do ano }\end{array}$ & $\begin{array}{c}\text { Condições } \\
\text { climáticas }\end{array}$ \\
\hline 1 & $8: 00-9: 20$ & 15 & Inverno & Chuvoso \\
2 & $7: 50-9: 10$ & 18 & Primavera & Chuvoso \\
3 & $8: 00-9: 05$ & 19 & Primavera & Ensolarado \\
4 & $7: 30-8: 40$ & 21 & Primavera & Nublado \\
5 & $6: 30-7: 35$ & 21 & Primavera & Ensolarado \\
6 & $8: 30-9: 40$ & 25 & Primavera & Ensolarado \\
7 & $7: 50-8: 55$ & 20 & Primavera & Chuvoso \\
8 & $7: 00-8: 15$ & 19 & Verão & Nublado \\
9 & $8: 30-9: 40$ & 25 & Verão & Chuvoso \\
10 & $8: 20-9: 30$ & 26 & Verão & Ensolarado \\
11 & $8: 05-9: 10$ & 19,5 & Verão & Ensolarado \\
12 & $7: 40-8: 45$ & 24 & Verão & Ensolarado \\
13 & $7: 35-8: 50$ & 20,5 & Outono & Chuvoso \\
14 & $7: 30-8: 45$ & 18 & Outono & Nublado \\
15 & $7: 20-8: 30$ & 17 & Outono & Ensolarado \\
16 & $7: 40-8: 50$ & 18 & Outono & Ensolarado \\
17 & $7: 40-8: 55$ & 16 & Outono & Nublado \\
18 & $7: 50-9: 00$ & 11 & Outono & Neblina \\
\hline
\end{tabular}



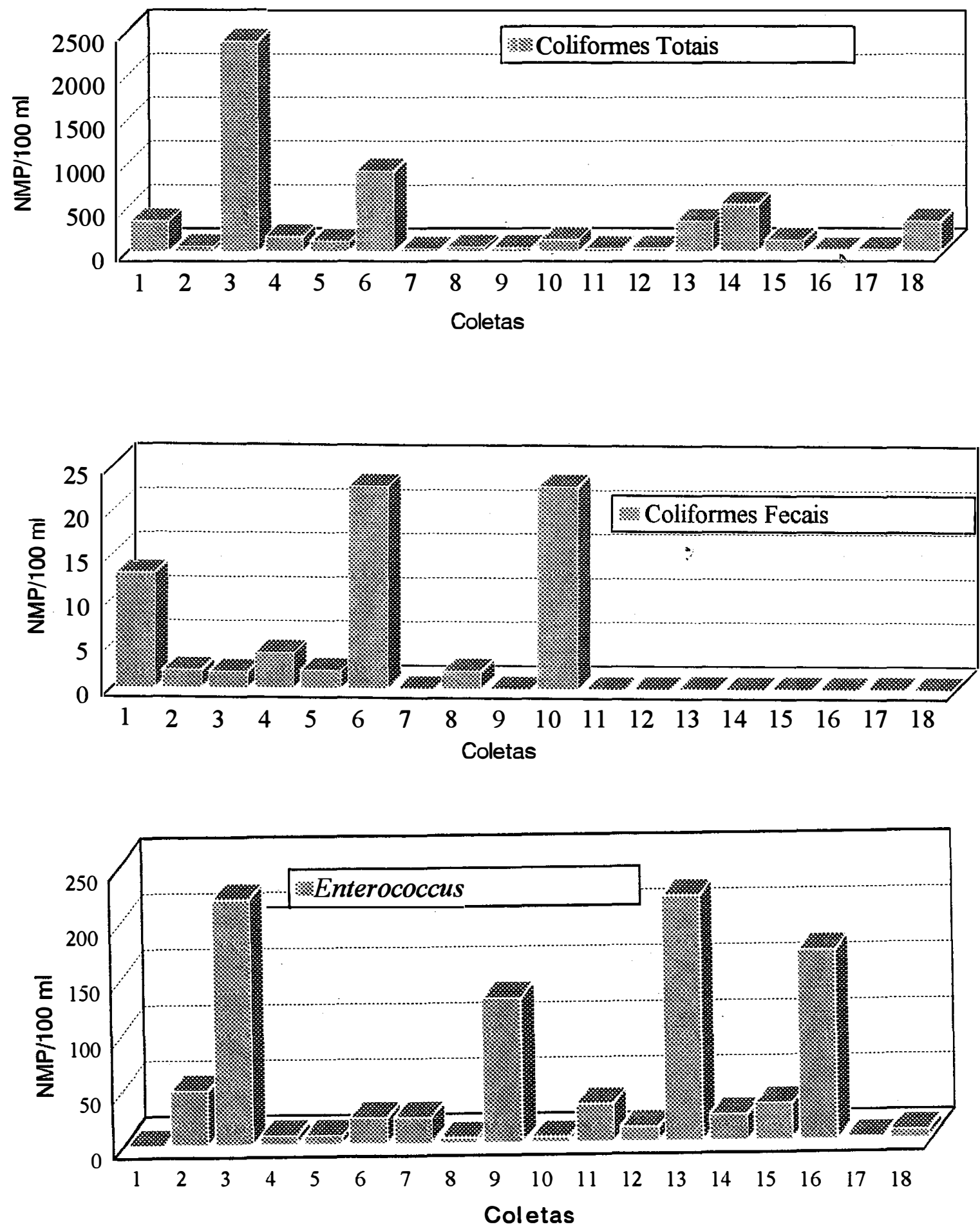

Figura 4. Número Mais Provável (NMP) de Coliformes Totais, Coliformes Fecais e Enterococcus $/ 100 \mathrm{ml}$ de água nas 18 coletas da nascente 1. 

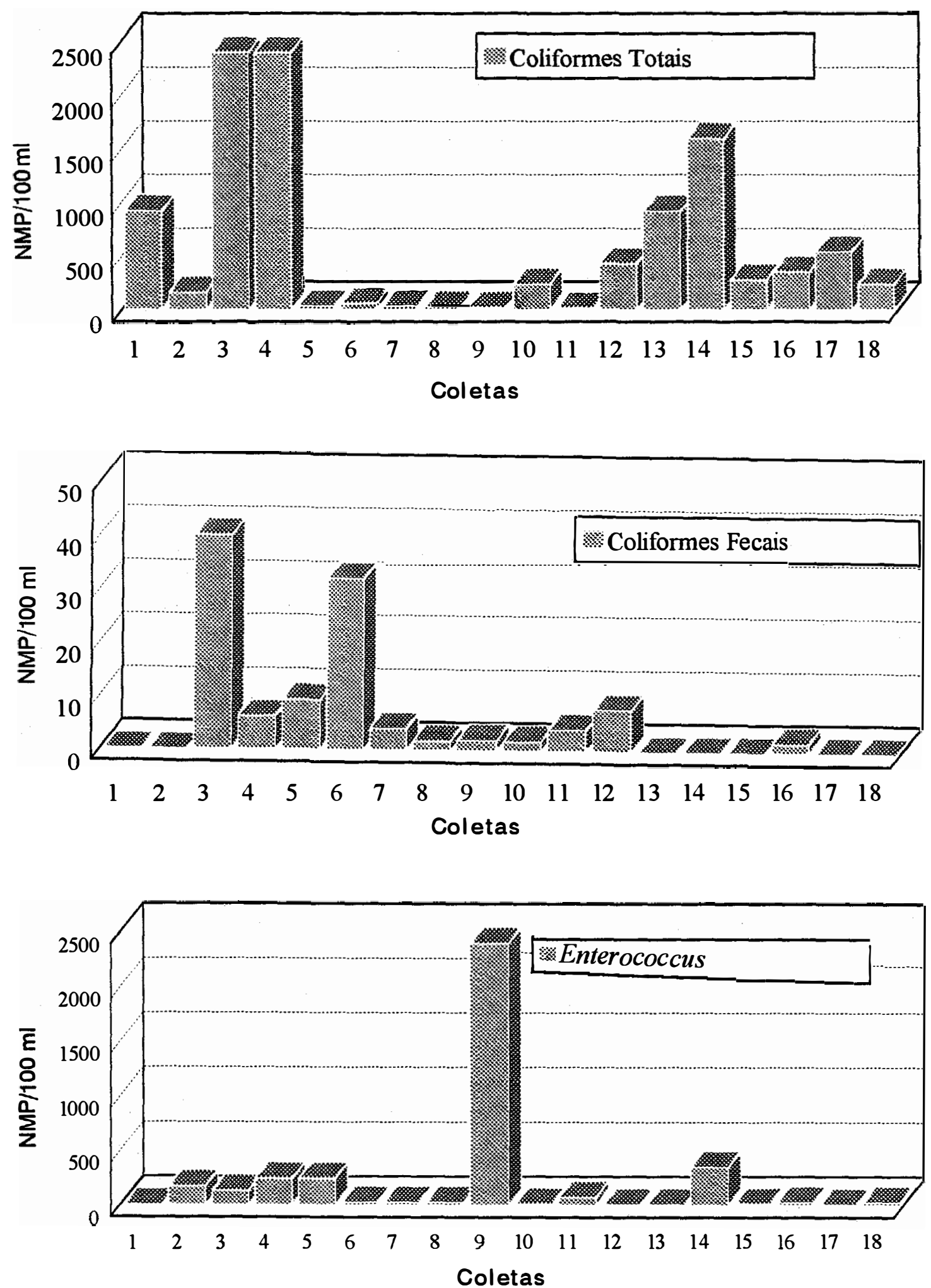

Figura 5. Número Mais Provável (NMP) de Coliformes Totais, Coliformes Fecais e Enterococcus $/ 100 \mathrm{ml}$ de água nas 18 coletas da nascente 2. 


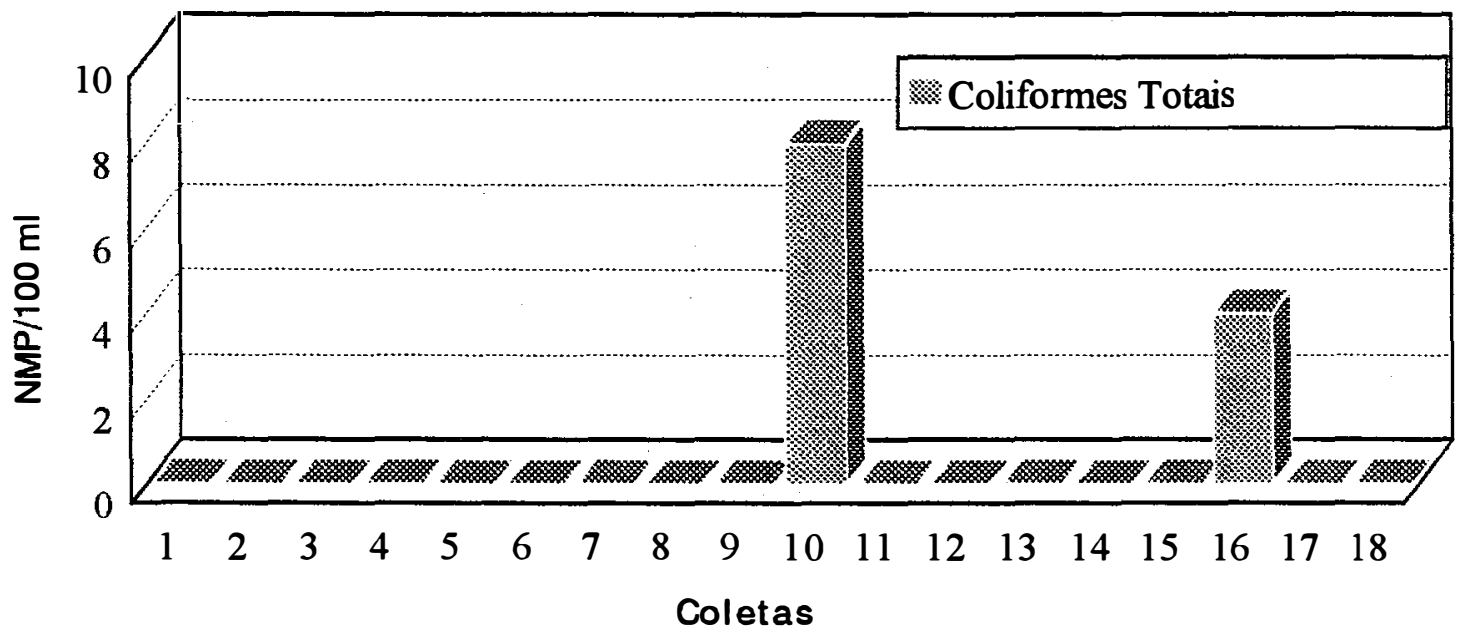

60
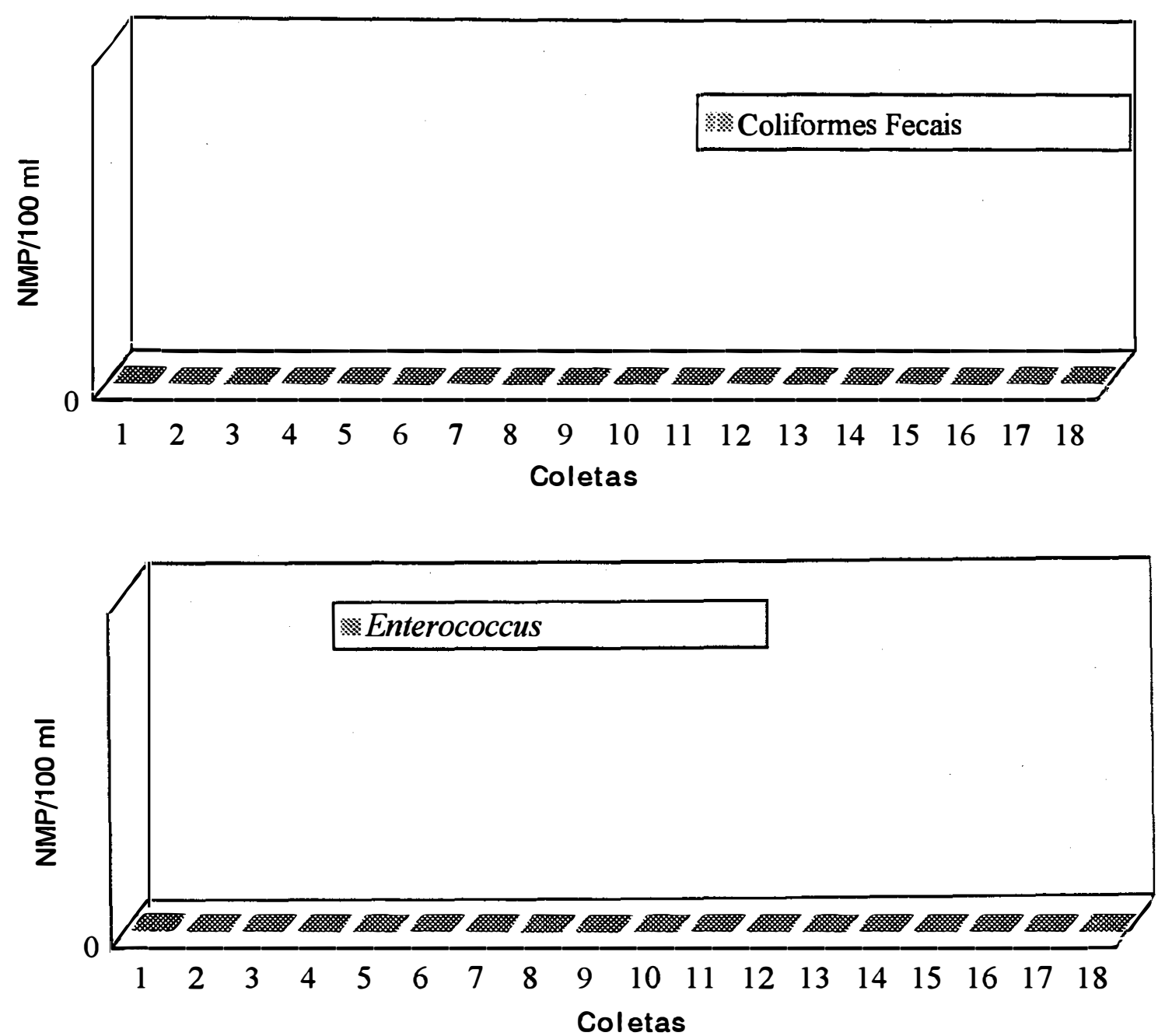

Figura 6. Número Mais Provável (NMP) de Coliformes Totais, Coliformes Fecais e Enterococcus $/ 100 \mathrm{ml}$ de água nas 18 coletas da nascente 3. 

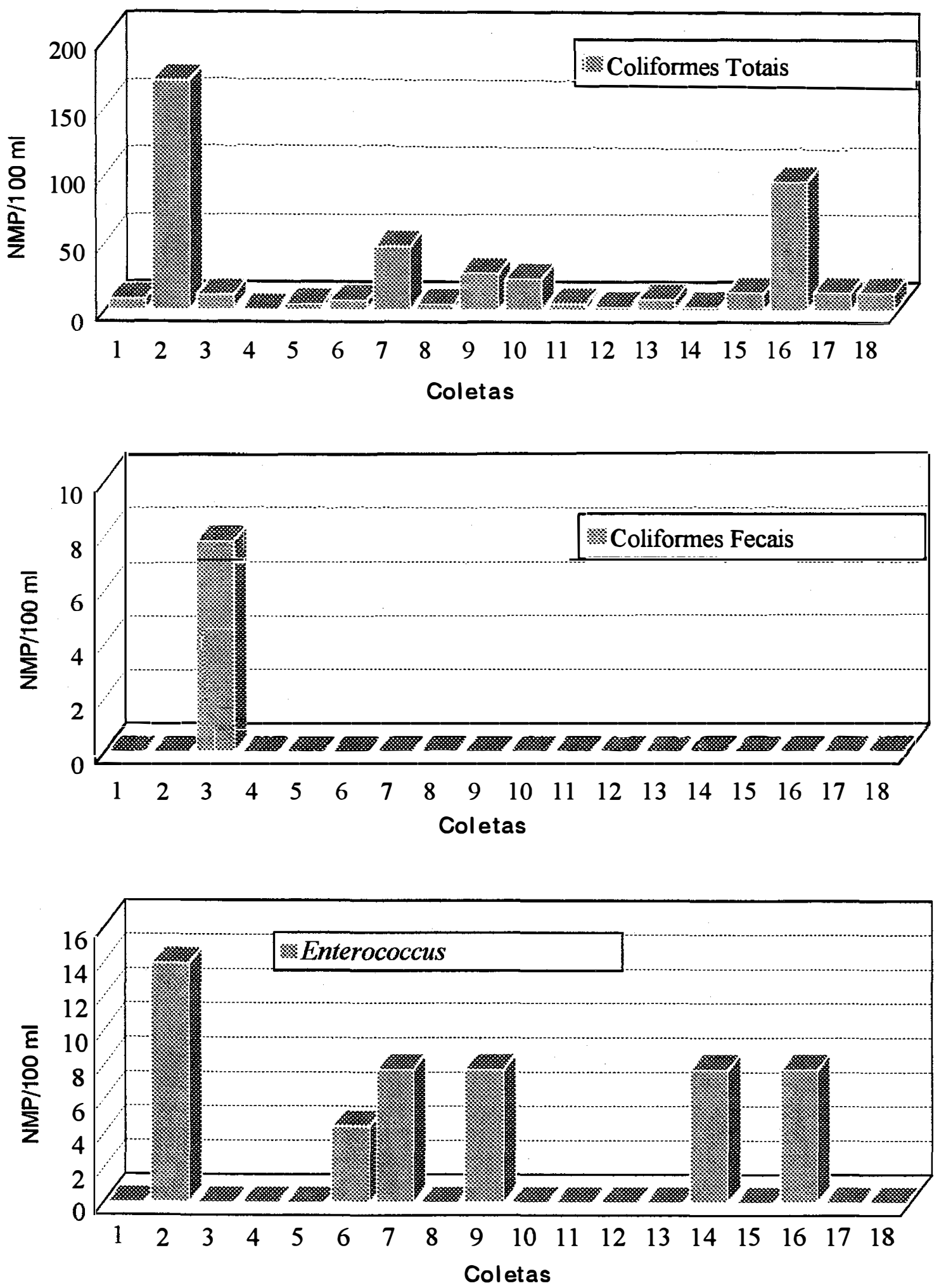

Figura 7. Número Mais Provável (NMP) de Coliformes Totais, Coliformes Fecais e Enterococcus $/ 100 \mathrm{ml}$ de água nas 18 coletas da nascente 4. 


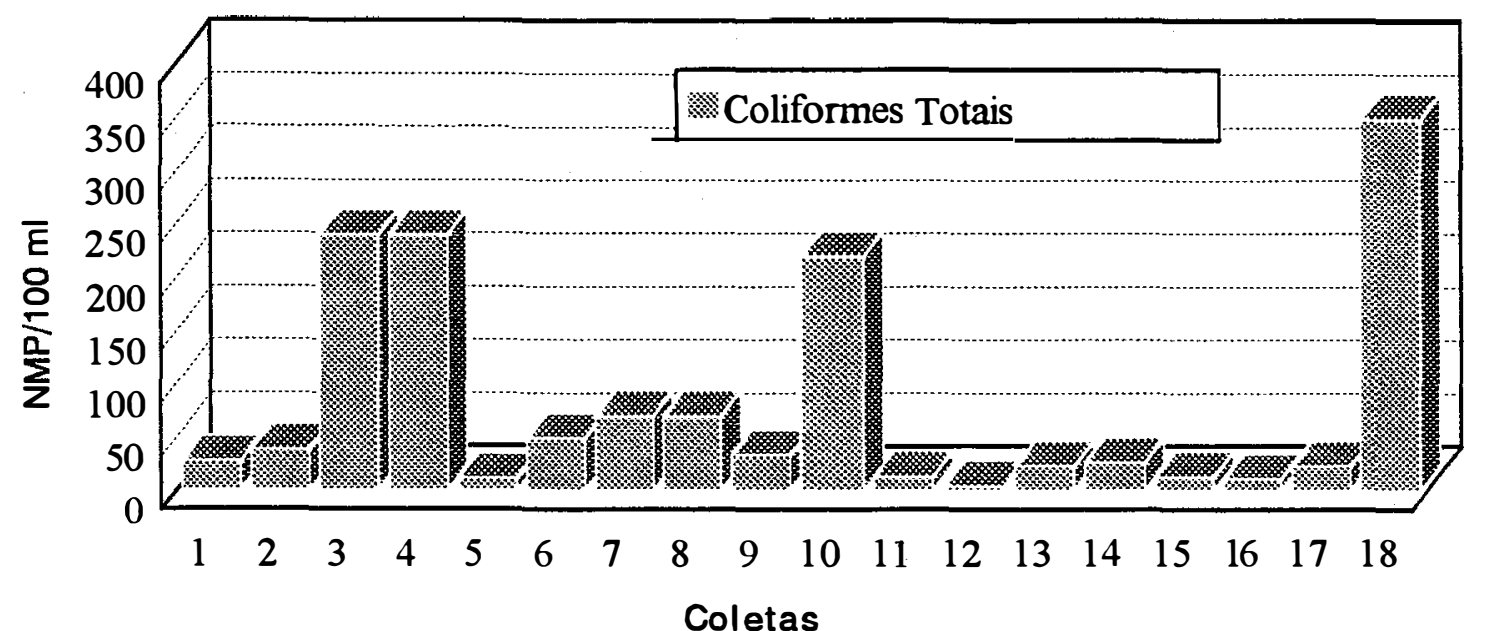

62
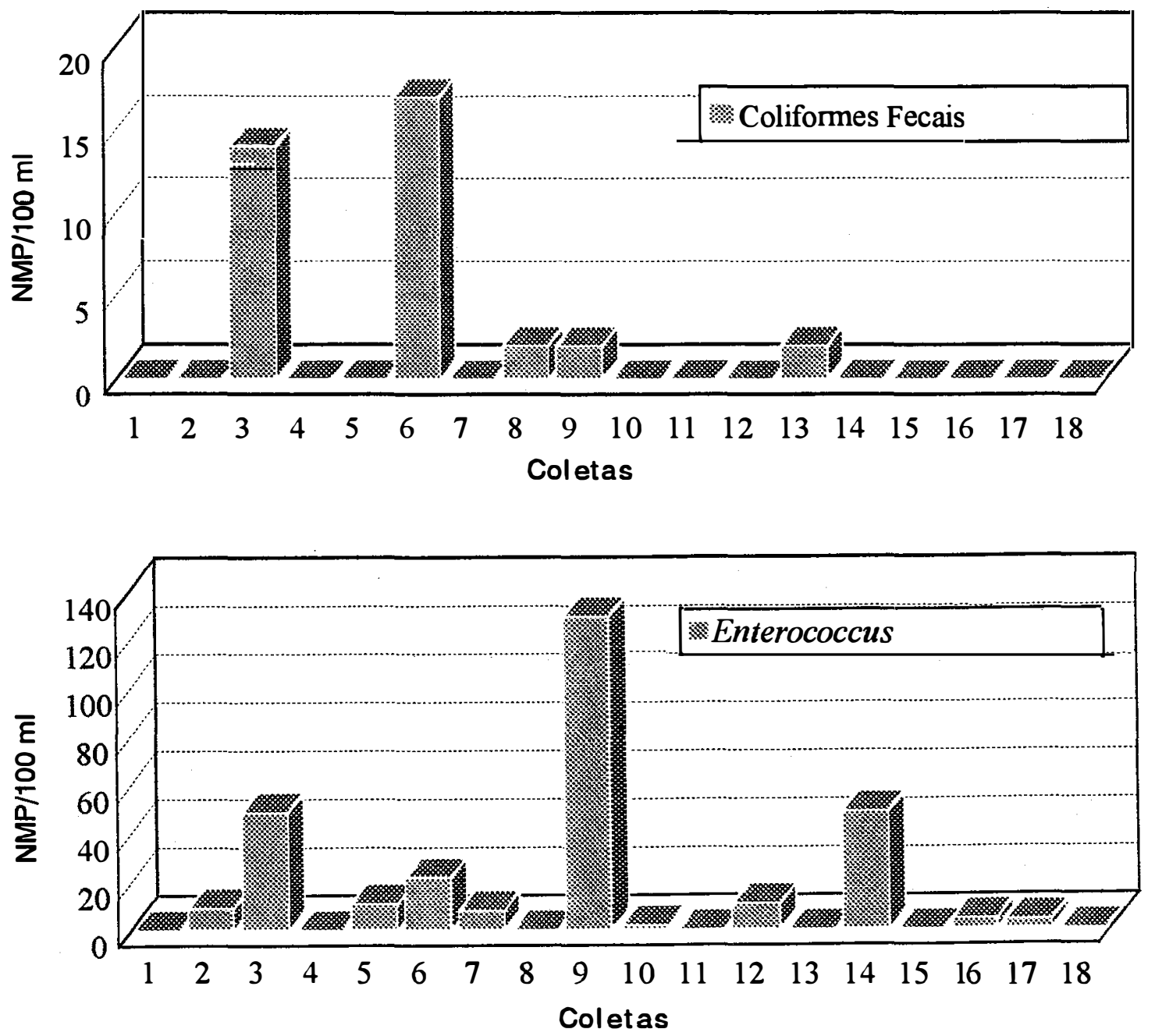

Figura 8. Número Mais Provável (NMP) de Coliformes Totais, Coliformes Fecais e Enterococcus $/ 100 \mathrm{ml}$ de água nas 18 coletas da nascente 5. 

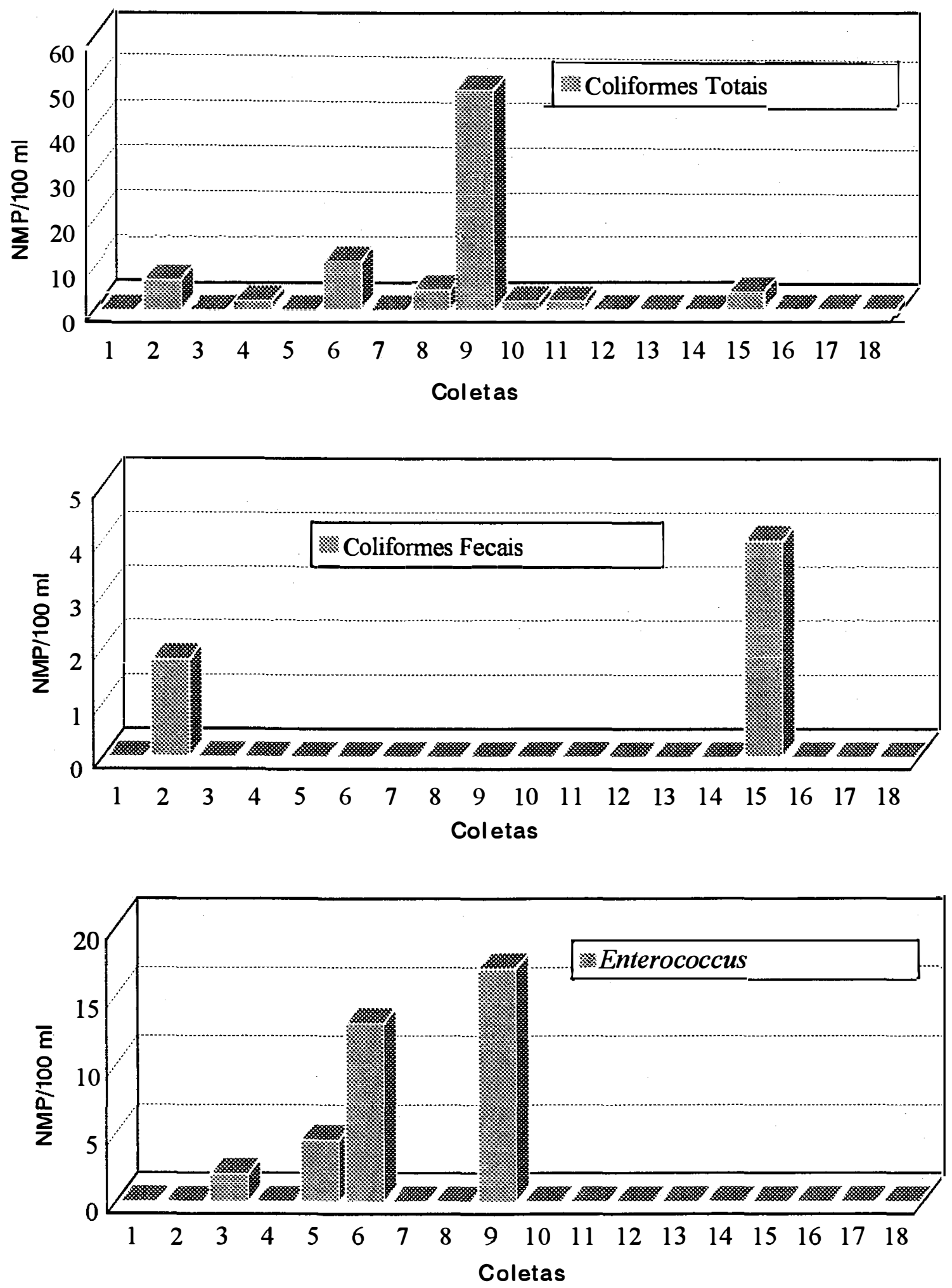

Figura 9. Número Mais Provável (NMP) de Coliformes Totais, Coliformes Fecais e Enterococcus/100 ml de água nas 18 coletas da nascente 6. 

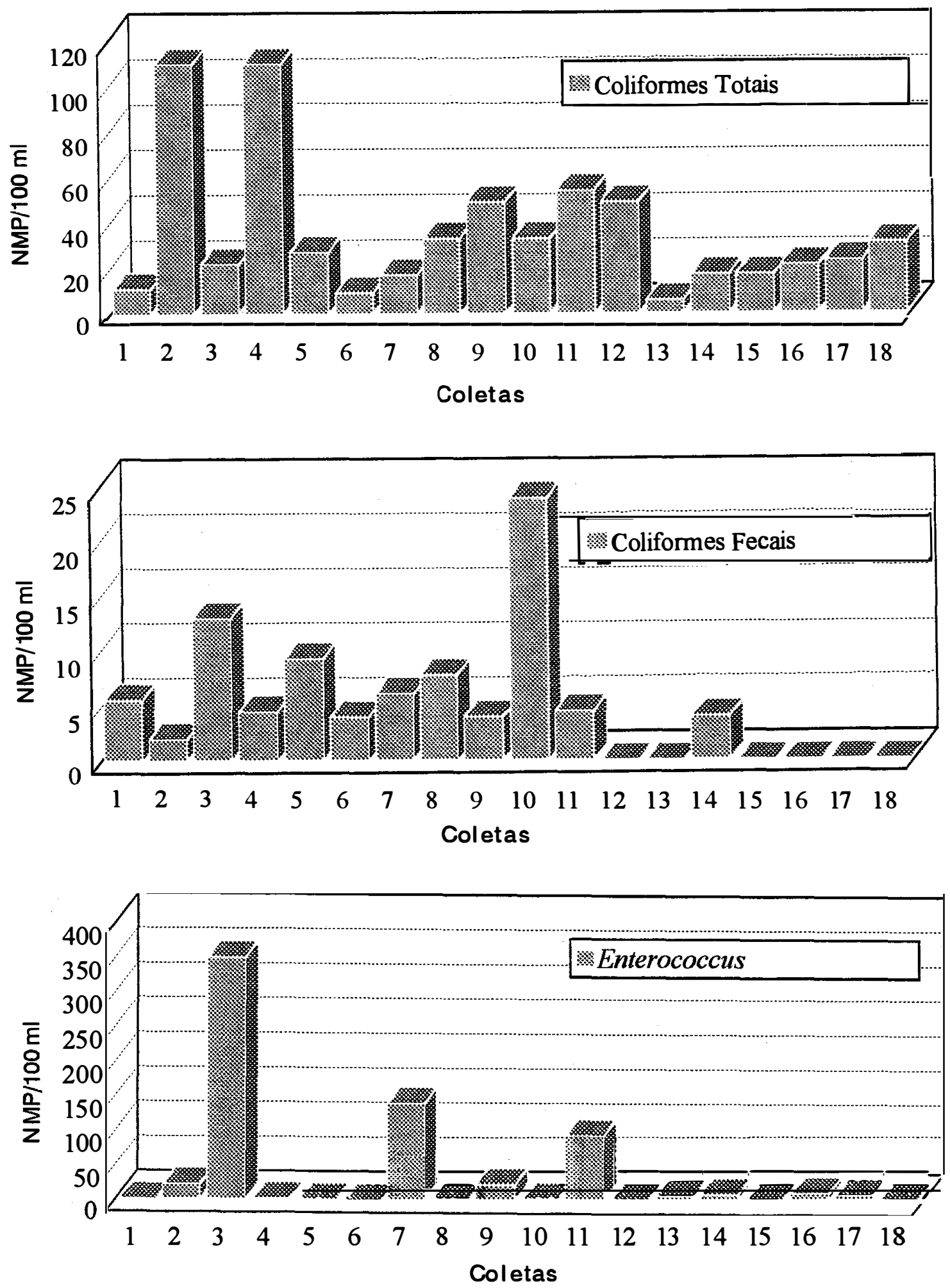

Figura 10. Número Mais Provável (NMP) de Coliformes Totais, Coliformes Fecais e Enterococcus $/ 100 \mathrm{ml}$ de água nas 18 coletas da nascente 7. 

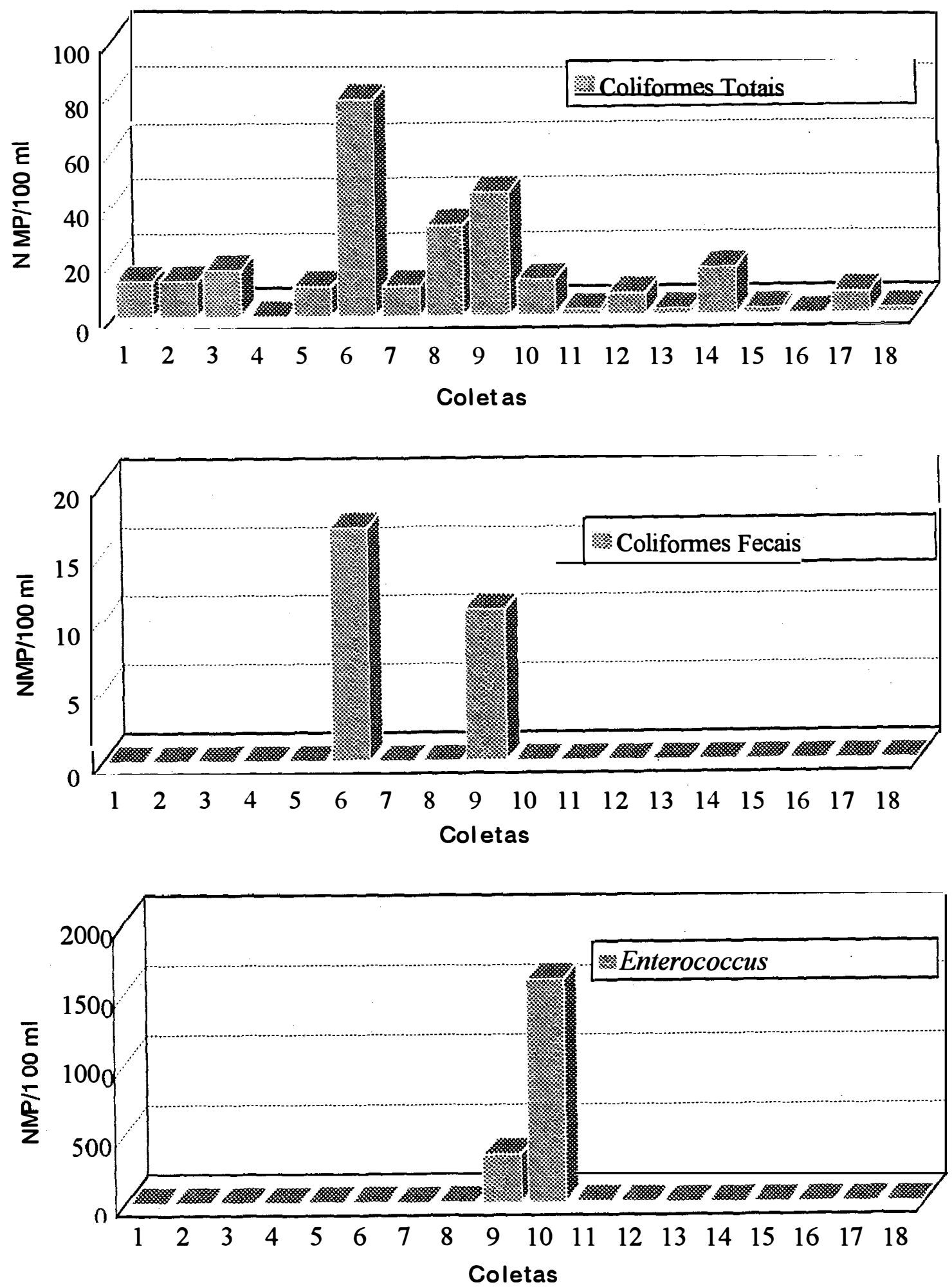

Figura 11. Número Mais Provável (NMP) de Coliformes Totais, Coliformes Fecais e Enterococcus $/ 100 \mathrm{ml}$ de água nas 18 coletas da nascente 8. 


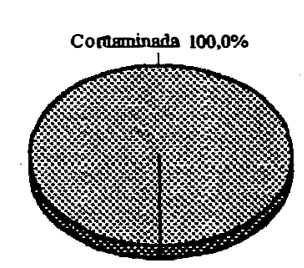

Coliformes Totais

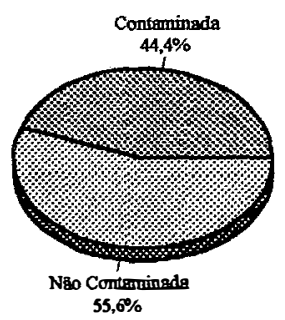

Coliformes Fecais

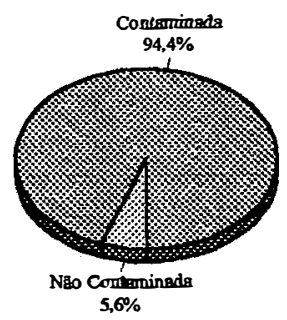

Enterococcus

Figura 12. Percentuais de contaminação por coliformes totais, coliformes fecais e Enterococcus, nas amostras da nascente 1.

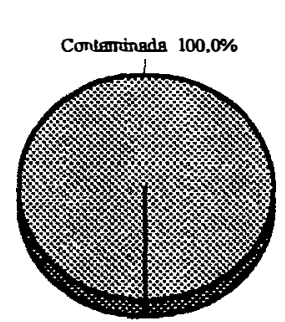

Colifiormes Totais

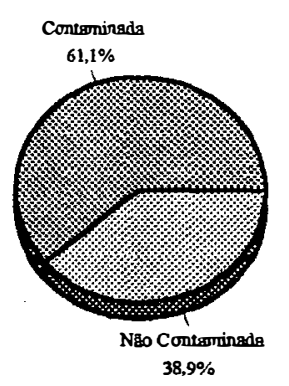

Coliformes Fecais

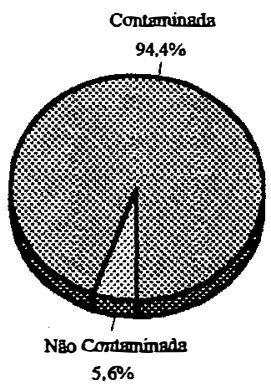

Enterococcus

Figura 13. Percentuais de contaminação por coliformes totais, coliformes fecais e Enterococcus, nas amostras da nascente 2. 


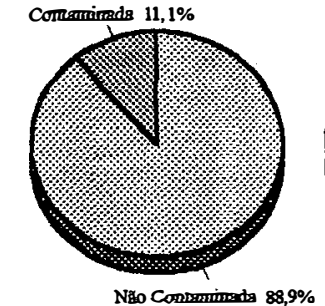

Coliformes Totais

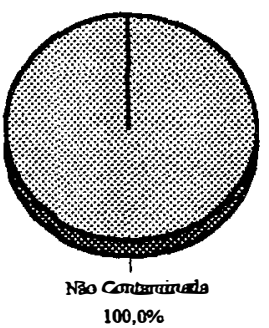

Coliformes Fecais

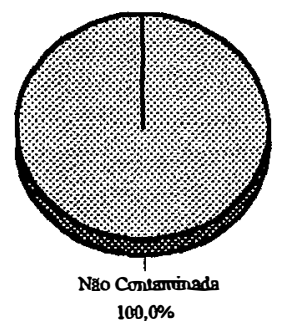

Enterococcus

Figura 14. Percentuais de contaminação por coliformes totais, coliformes fecais e Enterococcus, nas amostras da nascente 3.

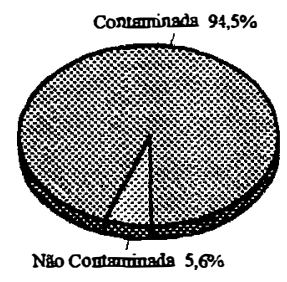

Coliformes Totais

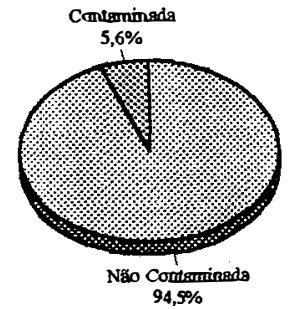

Colifiormes Fecais

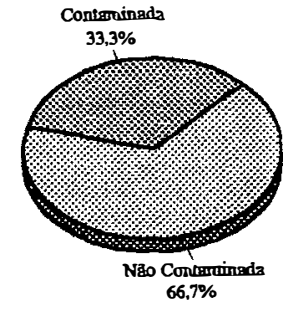

Enterococcus

Figura 15. Percentuais de contaminação por coliformes totais, coliformes fecais e Enterococcus, nas amostras da nascente 4. 


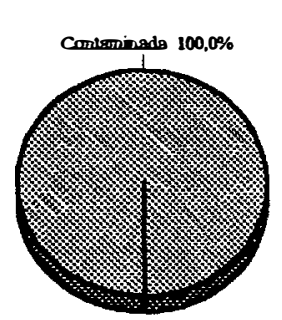

Coliformes Totais

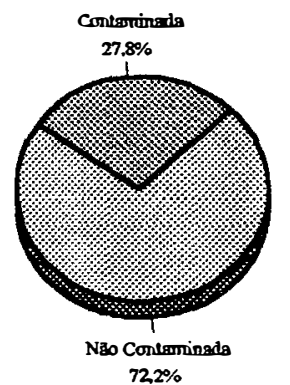

Coliformes Fecais

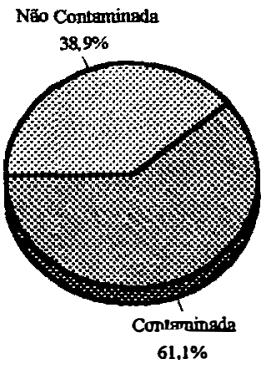

Enterococcus

Figura 16. Percentuais de contaminação por coliformes totais, coliformes fecais e Enterococcus, nas amostras da nascente 5.

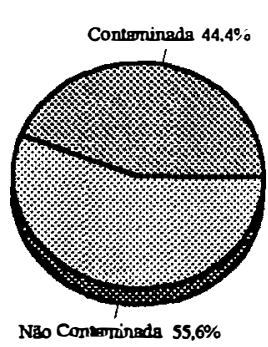

Coliformes Totais

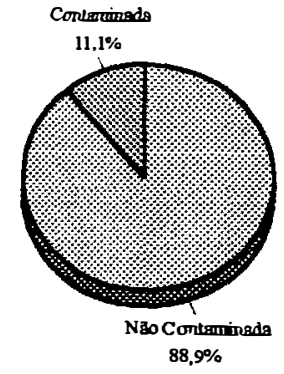

Colifiormes Fecais

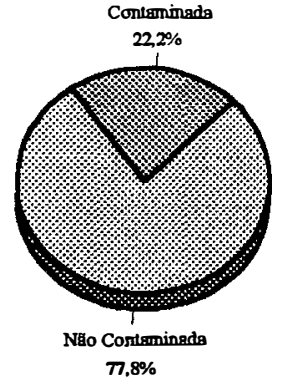

Enterococcus

Figura 17. Percentuais de contaminação por coliformes totais, coliformes fecais e Enterococcus, nas amostras da nascente 6. 


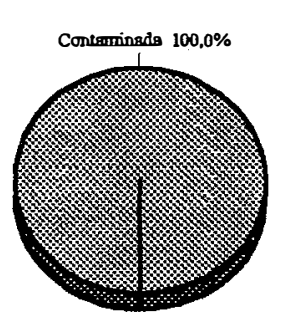

Coliformes Totais

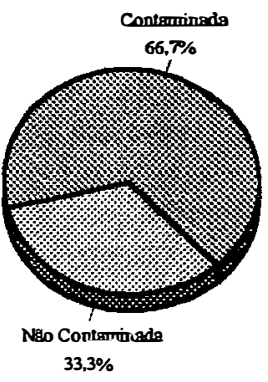

Coliformes Fecais



Enterococcus

Figura 18. Percentuais de contaminação por coliformes totais, coliformes fecais e Enterococcus, nas amostras da nascente 7.

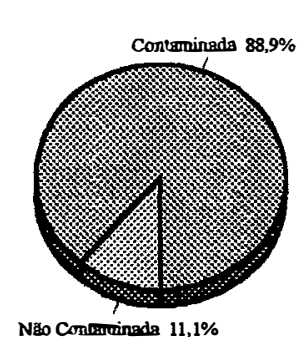

Coliformes Totais

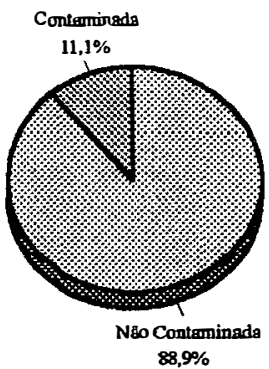

Colifiormes Fecais

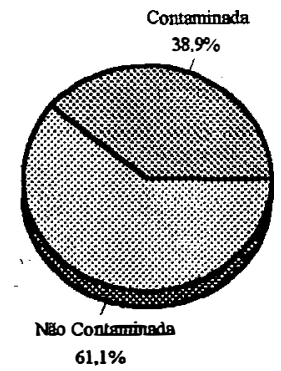

Enterococcus

Figura 19. Percentuais de contaminação por coliformes totais, coliformes fecais e Enterococcus, nas amostras da nascente 8. 
Pela análise dos resultados, vê-se que a água de 7 das 8 nascentes (bicas) analisadas estão impróprias para o consumo humano, algumas com índices de contaminação maiores, como é o caso das nascentes 1, 2, 5 e 7 que apresentaram-se contaminadas com coliformes totais em $100 \%$ das amostras analisadas e com coliformes fecais entre $27,8 \mathrm{e}$ $66,7 \%$.

As nascentes (bicas) 4 e 8 apresentaram-se contaminadas com coliformes totais em $94,5 \%$ e $88,9 \%$ das amostras analisadas e com coliformes fecais em 5,6\% e $11,1 \%$, ou seja, uma porcentagem um pouco menor que as anteriores, em relação a contaminação por coliformes totais, mas mesmo assim, não deixam de estar fora dos padrões de potabilidade e, portanto, não aptas para o consumo humano.

A nascente (bica) 6 apresentou-se com 44,4\% das amostras analisadas contaminadas com coliformes totais e com $11,1 \%$ das amostras contaminadas com coliformes fecais, sendo a mesma também considerada imprópria ao consumo humano.

A nascente (bica) 3 foi a única que não apresentou contaminação por coliformes fecais e por Enterococcus; apenas apresentou-se contaminada com coliformes totais em 2 das 18 coletas com menos de 10 ( 8 e 4) coliformes totais/100 ml de água e as mesmas não foram consecutivas. Assim, esta nascente pode ser considerada própria para o consumo humano.

Os resultados das contaminações por coliformes totais oscilaram durante as coletas ao longo dos 10 meses, onde temperaturas mais elevadas, mais baixas, chuvas 
e períodos de estiagem foram verificados, mostrando assim, a não influência direta das variações climáticas nos índices de contaminação das águas das nascentes analisadas.

Somente nas nascentes 1 e 2, é que se pode observar uma correlação entre períodos ou dias de coletas chuvosos (as 4 primeiras coletas e da $13^{a}$ a $15^{a}$ ) onde os números de coliformes totais foram maiores.

Já, para os coliformes fecais, percebe-se através dos gráficos que nas coletas de 1 a 10 foram detectadas as maiores contaminações, havendo uma diminuição aparente nas últimas, onde neste período final em apenas 2 coletas o tempo se apresentava chuvoso. Talvez, a maior incidência de contaminantes de origem fecal, possa estar relacionada com chuvas ocorridas, tanto em alguns dias anteriores às coletas, como no próprio dia das mesmas, uma vez que as maiores contaminações por coliformes fecais ocorreram nos períodos mais chuvosos de coletas.

A presença de Enterococcus também em 7 das 8 nascentes (bicas) analisadas, vem mais uma vez confirmar a não potabilidade bacteriológica da água das mesmas, face ao risco da presença de patógenos intestinais. Embora não tenha ficado bem caracterizada a influência direta das chuvas no aumento da contaminação por Enterococcus, em algumas nascentes, as maiores contaminações foram detectadas, ou em dias chuvosos de coletas ou após período chuvoso.

Outro aspecto importante constatado no presente trabalho, foi que em algumas amostras, não se detectou coliformes fecais e se detectou Enterococcus ou viceversa, mostrando que a análise simultânea para os dois grupos de indicadores fecais é 
importante, para uma melhor avaliação das condições bacteriológicas da água para consumo humano. 


\section{CONCLUSÕES}

Pelos resultados obtidos no presente trabalho podemos concluir que:

- sete das oito nascentes (bicas) analisadas durante 10 meses encontraram-se

fora dos padrões de potabilidade bacteriológica e, portanto, mostraram-se impróprias ao consumo humano;

- a incidência de coliformes fecais aumentou nos períodos de chuva, sendo necessária nesse período uma atenção redobrada dos órgãos competentes em alertar a população do risco que correm ao consumir água não tratada, principalmente nessa época, ou impedir que consumam.

- as variações das condições climáticas ocorridas nos dias de coleta de água, não interferiram significativamente no número de coliformes totais e Enterococcus, uma vez que as variações na intensidade destas bactérias ocorreram independentemente da temperatura, bem como de presença ou ausência de chuvas.

- a análise simultânea para os dois grupos de indicadores fecais é importante para uma melhor avaliação das condições bacteriológicas da água para consumo humano. 
- com estes resultados alarmantes, sabe-se que alguma providência deve ser tomada pelos órgãos competentes, a fim de não deixar a população que consome água das nascentes exposta a riscos de doenças veiculadas pela mesma, providência esta que pode ser a instalação de tratamento da água nessas nascentes (cloração), proteção do manancial contra possíveis contaminações ou interdição das mesmas. 


\section{REFERÊNCIAS BIBLIOGRÁFICAS}

A CAUSA da cólera. O Estado de São Paulo, São Paulo, 22 de abril, 1993.

ÁGUA. Notícias da Serra do Mar e Mata Atlântica. São Paulo, (3): 1-30, 1994.

ALARY, M. \& NADEAU, D. An outbreak of Campylobacter jejuni enterites associated with a community water suply. Canadian Journal of Public Health, Quebec, 81(4): 268-71, 1990. Apud. Food Science Technology Abstracts, Shinfield, 23(2), 1991. p.92. (Resumo).

ALVAREZ, M. de L.; WURGAFT, F.; ARAYA, M.; ESPINOZA, J. Typhoid fever in children of low and high socieconomic strata: comparison of hygiene habits. Revista de Saúde Pública, São Paulo, 24: 108-12, 1990. 
ALVES, M.N.;CAIRES, M.M. de; STEDTLER, A.G.M.; SANCHES, P.S. Análise comparativa de métodos para detecção de coliformes em águas para consumo humano. In: CONGRESSO BRASILEIRO DE ENGENHARIA SANITÁRIA E AMBIENTAL, 13, Goiânia, 1991. Anais. São Paulo, CETESB, 1991. 13p.

ANTAI, S.P. Incidence of Staphylococcus aureus, coliforms and antibiotic-resistant strains of Escherichia coli in rural water supplies in Port Harcourt. Journal of Applied Bacteriology, Reading, 62: 371-75, 1987.

APHA - AMERICAN PUBLIC HEALTH ASSOCIATION. Microbiological examination of water. In: ___ Standard methods for the examination of water and wastewater. 13.ed. Washington, 1971. Cap. 25, p.265-81; Cap. 32, p.405-9.

APHA - AMERICAN PUBLIC HEALTH ASSOCIATION. Microbiological examination of Water. In: ___ Standard methods for the examination of water and wastewater. 17.ed. Washington, 1989. Part 9000. p. 1-227.

BARBOSA, V.; WALDMAN, E.A.; FUJITA, M.; KITAMURA, C.; WALDMAN, C.C.S.; LACERDA, J.P.G. de. Imunidade relativa à poliomielite com a vacina oral trivalente tipo Sabin, em área da Grande São Paulo, SP (Brasil), 1982. Revista de Saúde Pública, São Paulo, 18: 19-29, 1984. 
BATALHA, B.H.L. A água que você bebe. São Paulo, CETESB, s.d., 39p.

BEALE, A.J. Imunização contra poliomielite. Anais Nestlé, São Paulo, (87): 39-43, 1969.

BURTON JR, G.A.; GUNNISON, D.; LANZA, G.R. Survival of pathogenic bacteria in various freshwater sediments. Applied Environmental Microbiology, Baltimore, 53(4): 633-8, 1987.

CARDENAS, V. SAAD, C.; VARONA, M,; LINERO, M. Waterborn cholera in Riohacha, Colombia, 1992. Bulletin of the Pan American Health Organization, Atlanta, 27(4): 313-30, 1993. Apud. Food Science Technology Abstracts, Shinfield, 26(4), p. 125, 1994. (Resumo).

CETESB - COMPANHIA DE TECNOLOGIA DE SANEAMENTO AMBIENTAL. Análises bacteriológicas da água. São Paulo, CETESB, 1991. 173p. (Série Didática, 1).

DADSWELL, J.V. Microbiological aspects of water quality and health. Journal of the Instituition of Water and Environmental Management, London, 4(6): 515-9, 1990. 
EDBERG, S.C.; ALLEN, M.J.; SMITH, D.B. Rapid specific autoanalytical method for the simultaneous detection of total coliforms and Escherichia coli from drinking water. Water Science Technology, Oxford, 21(3): 173-7, 1989.

EL-ABAGY, M.M. \& KAMEL, M.M. The coliphage test: a simple, rapid and economical method of assessing the quality of potable and natural waters in Egypt. Water Quality Bulletin, Burlington, 14(4): 198-201, 1989.

ELLIS, K.V. Water desinfection: a review with some consideration of the requirements of the third world. Critical Reviews in Enviromental Control, Boca Raton, 20: 341-407, 1991.

FAO. Water for lifie. Roma, 1994. 26p.

FERESU, S.P. \& SICKLE, J.V. Coliforms as a measure of sewage contamination of the River Zambezi. Journal of Applied Bacteriology, Reading, 68: 397-403, 1990.

FIGUEIREDO, R.M. de. Ocorrência de coliformes e estreptococos fecais em alimentos com baixo teor de umidade. Piracicaba, 1991. 77p. (Mestrado) - Escola Superior de Agricultura "Luiz de Queiroz"/USP. 
FLINT, K.P. The long-term survival of Escherichia coli in river water. Journal of Applied Bacteriology, Reading, 63: 261-70. 1987.

FRAZIER, W.C. \& WESTHOFF, D.C. Microbiología de los alimentos. 4.ed., Zaragoza, Acribia, 1993. p. 72-82; 629-36.

GALLO, C.R. Toxinfecções alimentares. Microbiologia de Alimentos II. ESALQ/Depto. de Tecnologia Rural, 1992. 164p.

GATTI, M. \& NEVIANE, E. A new simple medium for the detection of Enterococcus faecalis and Enterococcus faecium by measurement of condutance changes. Letters in Applied Microbiology, 17(2): 72-74, 1993.

HAGLER, A.N. \& MENDONÇA-HAGLER, L.C.S. Microbiologia sanitátia. In: ROITMAN, I. et al. ed. Tratado de microbiologia, São Paulo, Manole, 1988, v.1, p.85-102.

HAGLER, A.N. \& MENDONÇA-HAGLER, L.C.S. Microbiologia aquática. In: ROITMAN, I. et al. ed. Tratado de microbiologia, São Paulo, Manole, 1991., v.2. p.83-102. 
HAHN, T.; WIEDENMANN, A.; BOTZENHART, K. Improved methods for the evaluation of drinking water quality by detecting enterobacteria. Water Science Technology, Oxford, 21(3): 263-66, 1989.

HARTMAN, P.A. \& DEIBEL, R.H. The enterococci. In: SPECK, M.L. ed. Compendium of methods for the microbiological examination of foods. 2. ed., Washington, American Public Health Association, 1984. p.405-9.

HAVELAAR, A.H. \& DUNRING, M. Evaluation of the Anderson Baird-Parker direct plating method for enumerating Escherichia coli in water. Journal of Applied Bacteriology, Reading, 64: 89-98, 1988.

HIRAISHI, A. \& HORIE, S. Species composition and growth-temperature characteristics of coliforms in relation to their sources. Journal General Applied Microbiology, Tokio, 28: 139-54, 1982.

HOLMES, B. \& HUMPHRY, P.S. Identification of Enterobacteriaceae with the minitek system. Journal of Applied Bacteriology, Reading, 64: 151-61, 1988. 
HOLT, J.G.; KRIEG, R.N.; SNEATH, P.H.A.; STALEY, J.T.; WILLIAMS, S.T. Bergey's manual of determinative bacteriology, 9. ed. Baltimore, 1994. p.179;528

ICMSF - INTERNATIONAL COMMISSION ON MICROBIOLOGICAL SPECIFICATIONS FOR FOODS. Microorganismos de los alimentos 1 Tecnicas de análisis microbiológico. 2. ed., Toronto, University of Toronto Press, 1980. p.3-14.

JONES, K.; BETAIEB, M.; TELFORD, D.R. Thermophilic campylobacters in surface waters around Lancaster, U.K.: negative correlation with Campylobacter infections in the community. Journal of Applied Bacteriology, Reading, 69: 758-64, 1990.

JORET, J.C.; CERVANTES, P.; LEVI, Y.; DUMONTIER, N.; COGNET, L.; HASLEY, C.; HUSSON, M.O.; LECLERC, H. Rapid detection of Escherichia coli in water using monoclonal antibodies. Water Science Technology, Oxford, 21(3): 161-7, 1989.

LAVOIE, M.C. Identification of strains isolated as total and fecal coliforms and comparison of both groups as indicators of fecal polution in tropical climates. Canadian Journal Microbiology., Ottawa, 29(6): 689-93, 1983. 
LEE, R.J. \& COLE, S.R. Internal quality control samples for water bacteriology. Journal of Applied Bacteriology, Oxford, 76(3): 270-74. 1994.

LEVINE, W.C.; STEPHENSON, W.T.; CRAUN, G.F. Waterborne disease outbreaks. Journal of Food Protection, Ames, 54(1): 71-8, 1991.

MANDE, R. As novas vacinas. Anais Nestlé, São Paulo, (87): 14-7, 1968.

MARMO, J.C. \& JOLY, S. Sobre a bacteriologia de águas piracicabanas. Pesquisas sobre bacteriologia da água. Piracicaba, ESALQ/Instituto Zimotécnico, 1964a. p.112-22.

MARMO, J.C. \& JOLY, S. Água de consumo: sua bacteriologia. Pesquisas sobre bacteriologia da água. Piracicaba, ESALQ/Instituto Zimotécnico, 1964b. p.44-60.

MARTINS, M.T.; ALVES, M.N.; SANCHES, P.S.; SATO, M.I.M. Evaluation of the fecal coliforms/fecal streptococci ratio in the characterization of fecal pollution in a subtropical river. Revista de Microbiologia, São Paulo, 15(2): 94-102, 1984. 
MARTINS, M.T.; PESSOA; G.A.V.; SANCHES, P.S.; SATO, M.I.M.; MONTEIRO, C.K. Isolamento de Salmonella no ambiente aquático: significado sanitário. Revista de Microbiologia, São Paulo, 19(1): 29-39, 1988.

MEHLMAN, I.J. Coliforms, fecal coliforms, Escherichia coli and enteropathogenic $E$. coli. In: SPECK, M.L. ed. Compendium of methods for the microbiological examination of foods. 2.ed. Washington, American Public Health Association, 1984. p.265-81.

MILLSON, M.; BOKHOUT, M.; CARLSON, J.; SPIELBERG, L.; ALDIS, R.; BORCZYK, A.; LIOR, H. An outbreak of Campylobacter jejuni gastroenterites linked to meltwater contamination of a municial well. Canadian Journal of Public Health, Toronto, 82(1): 27-31, 1991. Apud. Food Science Technology Abstracts, Shinfield, 23(9), 1991. p.114. (Resumo).

MOORE, A.C.; HERWALDT, B.L.; CRAUN, G.F.; CALDERON, R.L.; HIGHSMITH, A.R.; JURANE, K.D.D. Waterborne diseases in the United States, 1991 and 1992. Journal American Water Works Association, Atlanta, 86(2): 87-99, 1994. Apud. Food Science Technology Abstracts, Shinfield, 26(5), 1994. p.114. (Resumo).

NEVES, J. Cólera, risco e desafio. Merck, 1991. 92p. 
NIX, P.G. \& HOLMES, E.V.S. Detection of coliform bacteria in drinking water using the coliform equivalent (CE) test. Water Quality Bulletin, Burlington, 14(4): 191$227,1989$.

PIRACICABA. SERVIÇO MUNICIPAL DE ÁGUA E ESGOTO DE PIRACICABA. Cuidado, bica contaminada. Imprensa Oficial do Município, 1993, 12p.

POURCHER, A.M.;DEVRIESE, L.A.; HERNANDES, J.F.; DELATTRE, J.M. Enumeration by a miniaturized method of Escherichia coli, Streptococcus bovis and enterococci as indicators of the origin of faecal pollution of waters. Journal of Applied Bacteriology, Reading, 70: 525-30, 1991.

RIVILLA, R. \& GONZALES, C. Simplified methods for the microbiological evaluation of bottled natural mineral water. Journal of Applied Bacteriology, Reading, 64: 273-78. 1988.

SAÚDE registra 15.240 casos de cólera no país. O Estado de São Paulo, São Paulo, 10 jul. 1992. 
STEHR-GREEN, J.; MITCHELL, P.; NICHOLLS, C.; McEWAN, S.; PAYNE, A. Campylobacter enterites - New Zealand, 1990. Morbidity and Mortality Weekly Report, Porirua, 40(7): 116-17,123, 1991. Apud. Food Science Technology Abstracts, Shinfield, 23(2), 1991. p.88. (Resumo).

TAUXE, R.V.; HOLMBERG, S.D.; DODIN, A.; WELLS, J.V.; BLAKE, P.A. Epidemic cholera in Mali: high mortality and multiple routes of transmission in a famine area. Epidemiology and Infection, Atlanta, 100(2): 279-89, 1988. Apud. Food Science Technology Abstracts, Shinfield, 22(4), 1990. p.32. (Resumo).

TOBIN, R.S. \& SMITH, D.K. Criteria for the microbiological quality of well water in Canada. Water Quality Bulletin, Burlington, 14(4): 175-87. 1989.

TODD, E.C.D. Foodborne and waterborne disease in Canada 1984. Annual Summary. Journal of Food Protection, Ames, 52(7): 503-11, 1989.

VERTONI, P.C. Alimentação, higiênie e saúde pública. Microbiologia de Alimentos II. ESALQ/Depto. Tecnologia Rural, 1992. 164p. 
VERTONI, P.C. \& GALLO. C.R. Utilização de cloradores por difusão em poços rasos cisternas para garantia da potabilidade da água, ESALQ/USP. SEBRAE, Piracicaba, 1994, 66p. (Cursos Agrozootécnicos).

WALDMAN, E.A.; BARBOSA, V.; FUJITA, M.; WALDMAN, C.C.S.; LACERDA, J.P.G. de. Aspectos epidemiológicos e imunitários da poliomielite em crianças menores de um ano em área da região da Grande São Paulo, Brasil. Revista de Saúde Pública, São Paulo, 17: 9-22, 1983. 